\title{
Floristic surveys of Restinga Forests in southern Bahia, Brazil, reveal the effects of geography on community composition
}

\author{
Levantamento florístico de florestas de Restinga do Sul da Bahia, Brasil, revela o efeito da \\ geografia na composição das comunidades
}

\author{
Moabe Ferreira Fernandes ${ }^{1,3}$ \& Luciano Paganucci de Queiroz $^{2}$
}

\begin{abstract}
The Restinga forests of southern Bahia state, Brazil, grow on sandy coastal Quaternary sediments. As their floras are relatively poorly known, the present study assessed their floristic compositions. We surveyed four sites at Maraú and Itacaré and identified 302 angiosperm species belonging to 184 genera of 75 families. The most species rich families were: Fabaceae (35 species), Myrtaceae (25), Rubiaceae (21), Sapotaceae (13), Bromeliaceae (12), Annonaceae (11), Erythroxylaceae (10), Melastomataceae (9), and Apocynaceae (8). Local floras include elements with distributions restricted to the Atlantic Forest domain, those disjunct between the Amazon and Atlantic Forest domains, and those also occurring in moist forests and dry vegetation of central Brazil. The hypothesis that the floristic compositions of restinga forests are influenced by neighboring wet forests was tested using cluster and principal component analyses of eleven restinga forests and nine Atlantic wet forest sites. The results supported five main groups, with most of them including both restinga forests and their adjacent wet forest sites, thus corroborating the hypothesis that wet forests in geographical proximity greatly influence the floristic compositions of restinga forests.
\end{abstract}

Key-word: coastal vegetation, Atlantic Forest domain, flora, similarity.

\section{Resumo}

As florestas de Restinga do baixo-sul da Bahia, Brasil, encontram-se sobre sedimentos arenosos do Quaternário costeiro. Como sua flora é relativamente pouco conhecida, o presente estudo avaliou sua composição florística. Foram inventariadas quatro áreas nos municípios de Maraú e Itacaré e identificadas 302 espécies de angiospermas, distribuídas em 184 gêneros e 75 famílias. As famílias mais ricas em espécies foram: Fabaceae (35 espécies), Myrtaceae (25), Rubiaceae (21), Sapotaceae (13), Bromeliaceae (12), Annonaceae (11), Erythroxylaceae (10), Melastomataceae (9) e Apocynaceae (8). A flora local inclui elementos de distribuição restrita à Mata Atlântica, disjunta entre Amazônia e Mata Atlântica e florestas úmidas e a vegetação seca do Brasil central. A hipótese de que a composição florística das florestas de Restinga é influenciada pelas florestas pluviais geograficamente próximas foi testada usando análises de agrupamento e de componentes principais com onze áreas de florestas de Restinga e nove de florestas pluviais da Mata Altântica. Os resultados sustentaram cinco grupos principais, a maioria incluindo áreas de floresta de restinga e florestas pluviais adjacentes, corroborando a hipótese de que a proximidade geográfica aos estoques florísticos das florestas pluviais tem grande efeito na composição das florestas de Restinga.

Palavras-chave: vegetação costeira, Domínio Mata Atlântica, flora, similaridade.

\section{Introduction}

The word "Restinga" designates vegetation established on sandy Quaternary substrates subject to marine or fluvial-marine influences (Flexor et al. 1984; Sugiyama 1998). This definition encompasses a variety of plant communities that can vary greatly in terms of their physiognomic, floristic, and structural features (Assis et al. 2004). These vegetation complexes are organized along a sea-to-continent gradient, with positive correlations between species richness and size (Araújo 2000).

\footnotetext{
Universidade Estadual de Feira de Santana, Programa de Pós-Graduação em Botânica, 44036-900, Feira de Santana, BA, Brazil

${ }^{2}$ Universidade Estadual de Feira de Santana, Depto. Ciências Biológicas, 44036-900, Feira de Santana, BA, Brazil.

${ }_{3}^{3}$ Author for correspondence: moabeffernandes@gmail.com
} 
Restinga vegetation has great ecological value, serving as shelter for plant populations that are rare in other forest types in the Atlantic Forest domain (hereinafter Atlantic domain; Scarano 2009) and for endangered animals (Rocha et al. 2005) - and are used by traditional coastal communities for food, medicines, and raw materials for craft work (Menezes et al. 2009). These vegetation forms are also responsible for the maintenance of water resources (Dorneles \& Weachter 2004; Scherer et al. 2005).

Despite their great social and ecological importance, Restingas are some of the least-known vegetation types in Brazil in terms of their diversity and conservation status (Rocha et al. 2005), and basic information about areas occupied by Restinga vegetation fragments is lacking at both regional and continental scales (Rocha et al. 2007).

Studies encompassing Restinga vegetation are still incipient and have been unequally distributed across Brazil's geopolitical regions. Southern and southeastern Restinga sites have been more intensively studied (Lacerda et al. 1984; Araújo 2000; Martins et al. 2008; Lima et al. 2011), although Guedes et al. (2006) highlighted our lack of knowledge about the floristic and phytosociological structures of restinga vegetation in São Paulo State. Most of the works produced so far have been limited to floristic and vegetational aspects, with little emphasis on environmental patterns and processes. Bahia State has the longest coastline in the country (ca. $1200 \mathrm{~km}$ ), but studies there have been scarce and concentrated mostly along its northern shore (e.g., Britto et al. 1993; Queiroz 2007; Menezes et al. 2009; Queiroz et al. 2012).

Restingas are highly diverse habitats, although they generally harbor fewer species than other forest types within the Atlantic domain (Almeida Jr. et al 2009; Lima et al. 2011). Restinga vegetation is normally established on geologically recent sediments originating from deposition by marine regressive movements during the Pleistocene and Holocene periods. The young ages of these habitats have not provided sufficient time for speciation to occur - a factor often cited as the principal explanation for their scarcity of endemic taxa (Scarano 2002; Castro et al. 2012). These communities are therefore composed mostly of elements from other vegetation types - with the Atlantic domain being considered the main source of their species (generally more than $50 \%$ of the total numbers of species) (Assis et al. 2004). However, there are also reports of contributions from Cerrado (Neotropical Savanna), Caatinga (Seasonally Dry Tropical Forests and Woodlands), and Amazonia floras (Cerqueira 2000; Sacramento et al. 2007; Castro et al. 2012).

Taking into consideration the young geological age and scarcity of endemism in Restinga vegetation, we hypothesize that the flora of Restinga forests is composed mostly of elements that have migrated from neighboring wet forest areas rather than arising from in situ speciation. This hypothesis can be tested by demonstrating that the floras of Restinga forests are more similar to those of geographically close rain forests than to other (more remote) Restinga forest sites, and we present here comparative analyses to that end. We also report the results of floristic studies of Restinga forests from southern Bahia that can help fill gaps in our knowledge of the floristic compositions of Restinga forests in an important center of diversity in the Atlantic domain.

\section{Materials and Methods}

Study areas

The survey areas encompassed four sites in southern Bahia State, Brazil (Fig. 1), in the municipalities of Itacaré (Mata do Santo Amaro - MAS) and Maraú (Mata do Caubi - MC; Mata da Estrada Maraú-Itacaré - MMI; and Mata da Piracanga - MP; Tab. 1). The region is part of the Atlantic domain, with a mean annual precipitation between 1,200 and 2,400 $\mathrm{mm}$, with the rainy season extending from March to July, without a dry period; the mean annual temperature is approximately 25 ${ }^{\circ} \mathrm{C}$, with small oscillations between the minimum and maximum mean temperatures of 20 and 26 ${ }^{\circ} \mathrm{C}$ - an Af climate type according to the Köppen (1948) system (C.E.I. 1993).

The Restinga Forests in the survey region grow on well-preserved coastal ridges ranging from 5 to $8 \mathrm{~m}$ a.s.l. The substrate is sandy, and originated from ocean regressions following the Pleistocene transgression (Martin et al. 1980). Forest fragments are surrounded by open, seasonally flooded grasslands (Silva \& Britez 2005 ) that grow in lowland areas between mountain ridges, with pools forming during the rainy period. These grasslands are characterized by a well-developed herbaceous layer with sparsely distributed woody plants (Silva \& Britez 2005). 


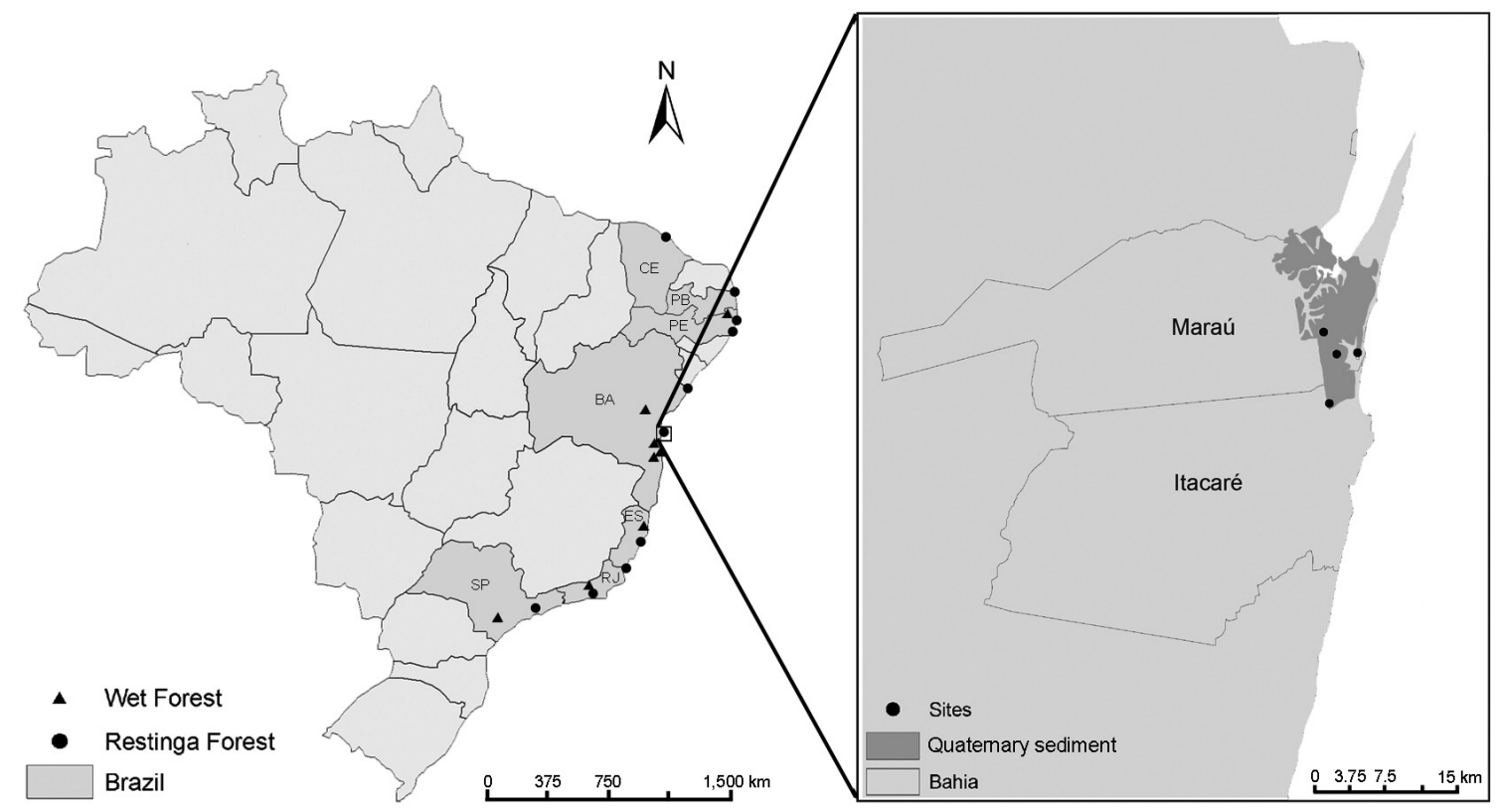

Figure 1 - Map of Brazil showing the locations of the areas used in the similarity analyses; circles indicate Restinga forests, and triangles wet forest areas. The inset shows the borders of the municipalities of Itacaré and Maraú (Bahia State), highlighting the distribution of the sandy Quaternary sediments and Restinga forest sites (circles) where the floristic surveys were conducted. Brazilian states with areas considered in the similarity and cluster analyses are indicated by darker grey shading: $\mathrm{BA}=$ Bahia; $\mathrm{CE}=$ Ceará; $\mathrm{ES}=$ Espírito Santo; $\mathrm{PB}=$ Paraíba; $\mathrm{PE}=\mathrm{Pernambuco}$; $\mathrm{RJ}=$ Rio de Janeiro; $\mathrm{SP}=$ São Paulo.

Figura 1 - Mapa do Brasil mostrando a localização das áreas comparadas nas análises de similaridade; círculos indicam áreas de florestas de Restinga e triângulos áreas de florestas pluviais. Em detalhe, limites dos municípios de Itacaré e Maraú (estado da Bahia), destacando a extensão de sedimentos arenosos do Quaternário e os sítios de florestas de Restinga (círculos) onde foram realizadas amostragem florística. Estados com áreas usadas nas análises de similaridade e agrupamento estão em cinza mais escuro: $\mathrm{BA}=\mathrm{Bahia}$; $\mathrm{CE}=\mathrm{Ceará}$; ES=Espírito Santo; PB=Paraíba; PE=Pernambuco; RJ= Rio de Janeiro; $\mathrm{SP}=$ São Paulo.

The four Restinga forest fragments studied here are classified as non-flooding Restinga forests, according Silva \& Britez (2005), although all of them show micro-topographical variations with certain localities subject to periodic flooding. The forest canopy is approximately $15 \mathrm{~m}$ tall, although some emergent species may reach $22 \mathrm{~m}$.

\section{Floristic Surveys}

Floristic surveys were carried out between March/2013 and February/2014 during nine field trips. The plant specimens were gathered and processed as described by Mori et al. (1989). Biological forms were assigned to each species following Whittaker (1975): trees (woody, $\geq 3$ $\mathrm{m}$ tall), shrubs (woody, $<3 \mathrm{~m}$ tall, usually multistemmed), herbs (self-standing, not woody), vines (climbing, woody or not woody), and epiphytes (growing on other plants). Trees and shrubs were collected even if they were not fertile, but other biological forms were sampled only when flowering and/or fruiting.

All collected materials were deposited in the State University of Feira de Santana herbarium (HUEFS). Identifications were made using taxonomic monographs and floras, by comparisons with identified specimens in the HUEFS and CEPEC (Herbário André Maurício Vieira de Carvalho, Centro de Pesquisas do Cacau) herbaria, and by consulting specialists of specific taxonomic groups. The species are arranged according the APG III (2009) system, with taxa names being updated according to the online databases of the Lista de Espécies da Flora do Brasil (<http://floradobrasil. jbrj.gov.br $>$ ) and the Missouri Botanical Gardens $(<$ http://tropicos.org $>)$. The occurrence of each species in specific Brazilian phytogeographical domains (Amazonia, Atlantic Forest, Caatinga, Cerrado, Pantanal, and Pampa) was determined by consulting the Lista de Espécies da Flora do Brasil 
website (<http://floradobrasil.jbrj.gov.br $>)$. Species were considered endemic to the Atlantic domain following Stehmann et al. (2009).

\section{Similarity and correlation analyses}

In order to test the putative effects of geographical distances from wet forests on the floristic compositions of Restinga forests, we prepared a binary matrix (presence/absence) based on the floristic lists of eleven Restinga forest and nine wet forest sites (Tab. 1; Fig. 1). All wet forest sites were within the Atlantic domain and less than $200 \mathrm{~km}$ from the Restinga forests sites investigated.

We excluded from the dataset any taxa identified only to the genus or family levels, or species with inaccurate identifications (affine [aff.] or confer [cf.]). Infraspecific ranks were not considered, and subspecies and different varieties were therefore regarded as the same species. The consolidated floristic list of the 20 areas comprised 2,431 species (Supplementary material).

The sites were compared by cluster analysis using Jaccard's coefficient (Mueller-Dombois \& Ellenberg 1974) and the Unweighted Pair Group Method using Arithmetic averages (UPGMA) with bootstrap support calculated from 1,000 replications using Past software (Hammer et al. 2001). Principal Component Analysis (PCA) was also performed using the same dataset and software cited above.

The Mantel Test using XLSTAT software was employed to assess correlations between the geographic and floristic distances of all sites (Addinsoft 2007). Floristic distances were estimated using the Jaccard coefficient, calculated with Past software (Hammer et al. 2001). Geographical distances were assessed by considering a central coordinate for each site, and the distances between areas were then measured using the Google Earth ruler tool. The significance of the Mantel test was calculated using the Monte Carlo test, with 10,000 permutations.

\section{Results}

The floristics of restinga forests in southeastern Bahia

A total of 302 angiosperm species belonging to 184 genera and 75 families were surveyed (Tab. 2), with 295 taxa being identified to the species level. The richest families in terms

Table 1 - Restinga and wet forests in evaluated in the multivariate analyses, with their acronyms, locations, coordinates, and vegetation types.

Tabela 1 - Áreas de florestas de restinga e florestas pluviais usadas na análise multivariadas, com sigla, localização, coordenadas e tipos vegetacionais.

\begin{tabular}{|c|c|c|c|c|c|c|}
\hline Sigla & Município & Estado & Latitude & Longitude & Formação & Referência \\
\hline ResSGA(CE) & $\begin{array}{l}\text { São Gonçalo do } \\
\text { Amarante }\end{array}$ & $\mathrm{CE}$ & -3.606944444 & -38.87027778 & Restinga & Castro et al. (2012) \\
\hline ResMara(PB) & Mataraca & $\mathrm{PB}$ & -6.486111111 & -34.94166667 & Restinga & $\begin{array}{c}\text { Oliveira-Filho \& Carvalho } \\
\text { (1993) }\end{array}$ \\
\hline OmbSVF(PE) & São Vicente Férrer & $\mathrm{PE}$ & -7.633333333 & -35.5 & $\begin{array}{l}\text { Ombrófila } \\
\text { Montana }\end{array}$ & Ferraz \& Rodal (2008) \\
\hline $\operatorname{ResCSA}(\mathrm{PE})$ & $\begin{array}{c}\text { Cabo de Santo } \\
\text { Agostinho }\end{array}$ & $\mathrm{PE}$ & -8.125 & -35.01527778 & Restinga & Sacramento et al. (2007) \\
\hline ResTam(PE) & Tamandaré & $\mathrm{PE}$ & -8.788888889 & -35.1125 & Restinga & Silva et al. (2008) \\
\hline ResCon(BA) & Conde & BA & -11.81277778 & -37.64027778 & Restinga & Menezes et al. (2009) \\
\hline OmbSTe(BA) & Santa Terezinha & BA & -12.85 & -39.96666667 & $\begin{array}{l}\text { Ombrófila } \\
\text { Submontana }\end{array}$ & $\begin{array}{l}\text { Carvalho-Sobrinho \& } \\
\text { Queiroz (2005), Neves } \\
(2005)\end{array}$ \\
\hline ResMaIt(BA) & Maraú-Itacaré & BA & -14.21694444 & -38.99833333 & Restinga & Este estudo \\
\hline $\mathrm{OmbBP}(\mathrm{BA})$ & Barro Preto & BA & -14.766666667 & -39.53333333 & $\begin{array}{l}\text { Ombrófila } \\
\text { Montana }\end{array}$ & Amorim et al.(2009) \\
\hline OmbUna(BA) & Una & BA & -15.16666667 & -39.05 & $\begin{array}{l}\text { Ombrófila } \\
\text { Tabuleiro }\end{array}$ & Amorim et al.(2008) \\
\hline
\end{tabular}




\begin{tabular}{|c|c|c|c|c|c|c|}
\hline Sigla & Município & Estado & Latitude & Longitude & Formação & Referência \\
\hline OmbAra(BA) & Arataca & $\mathrm{BA}$ & -15.16666667 & -39.33333333 & $\begin{array}{l}\text { Ombrófila } \\
\text { Montana }\end{array}$ & Amorim et al.(2009) \\
\hline $\mathrm{OmbCam}(\mathrm{BA})$ & Camaca & BA & -15.38333333 & -39.55 & $\begin{array}{l}\text { Ombrófila } \\
\text { Montana }\end{array}$ & Amorim et al.(2009) \\
\hline OmbLin(ES) & Linhares & $\mathrm{ES}$ & -19.2 & -40.03333333 & $\begin{array}{l}\text { Ombrófila } \\
\text { Tabuleiro }\end{array}$ & Peixoto et al. (2008) \\
\hline ResVit(ES) & Vitória & ES & -20.25833333 & -40.275 & Restinga & Pereira \& Assis (2000) \\
\hline ResSJB(RJ) & São João da Barra & $\mathrm{RJ}$ & -21.73333333 & -41.03333333 & Restinga & $\begin{array}{c}\text { Assumpção \& Nascimento } \\
\text { (2000) }\end{array}$ \\
\hline $\mathrm{OmbCMa}(\mathrm{RJ})$ & $\begin{array}{c}\text { Cachoeiras de } \\
\text { Macaú }\end{array}$ & $\mathrm{RJ}$ & -22.48333333 & -42.88333333 & $\begin{array}{l}\text { Ombrófila } \\
\text { Submontana }\end{array}$ & Kurtz \& Araújo (2000) \\
\hline ResMar(RJ) & Maricá & $\mathrm{RJ}$ & -22.91805556 & -42.81694444 & Restinga & Lemos et al. (2001) \\
\hline ResBer(SP) & Bertioga & SP & -23.75083333 & -45.97 & Restinga & Martins et al. (2008) \\
\hline ResBer2(SP) & Bertioga & SP & -23.75083333 & -45.97 & Restinga & Martins et al. (2008) \\
\hline $\mathrm{OmbSBa}(\mathrm{SP})$ & Sete Barras & SP & -24.23555556 & -48.07833333 & $\begin{array}{l}\text { Ombrófila } \\
\text { Submontana }\end{array}$ & Ziparro et al. (2005) \\
\hline
\end{tabular}

of their numbers of species were: Fabaceae (35 species), Myrtaceae (25), Rubiaceae (21), Sapotaceae (13), Bromeliaceae (12), Annonaceae (11), Erythroxylaceae (10), Melastomataceae (9), and Apocynaceae (8). Together, these families comprised $47.7 \%$ of the total number of species sampled. The richest genera were Myrcia (12 species), Erythroxylum (10), Aechmea (8), Miconia (8), and Psychotria (7).

Among biological forms, trees were the most abundant (213 species / 70.5\%), followed by shrubs (39/12.9\%), vines ( $24 / 7.9 \%)$, herbs $(19 / 6.3 \%)$, and epiphytes (7 / 2.3\%).

Phytogeographical domain assignments resulted in 144 species (47.7\%) identified as being endemic to the Atlantic domain, 34 species (11.2\%) disjunct between the Atlantic and Amazonia domains, 72 species (23.8\%) continuously distributed throughout the Atlantic and Amazonian domains, and $45(14.9 \%)$ throughout the Atlantic, Caatinga, and Cerrado domains. Among the species endemic to the Atlantic domain, 58 (19.2\%) were restricted to the area between southern Bahia and northern Espírito Santo.

Five species encountered in the study area are probably endemic to Restinga vegetation: Abarema turbinata (Benth.) Barneby \& J.W.Grimes, Leptolobium bijugum (Spreng.) Vogel, Parkia bahiae H.C.Hopkins (Fabaceae), Pagamea harleyi Steyerm. (Rubiaceae), and Schefflera selloi (Marchal) Frodin \& Fiaschi (Araliaceae).
Similarity and correlation analyses

Similarity analysis indicated the formation of five groups $(\mathrm{A}-\mathrm{E})$ with low similarity values, but with high support values, except group A (Fig. 2). Four groups include Restinga and wet forests, with: Group A comprising the sites in Rio de Janeiro and southern Espírito Santo states; group B comprising the sites located in Bahia State north of Todos os Santos Bay to Paraíba State; group C comprising the only site examined in Ceará State; group D comprising sites in southern Bahia and northern Espírito Santo states; and group E comprising the sites in São Paulo State.

PCA axis 1 and 2 (accounting for $34.4 \%$ of the observed variance) supported the separation of groups $\mathrm{D}$ and $\mathrm{E}$ from a group formed by the $\mathrm{A}, \mathrm{B}$ and $C$ sites. The Mantel test indicated a significant negative correlation between geographic distance and floristic similarities $(\mathrm{r}=-0.452 ; \mathrm{p}<0.0001)$.

\section{Discussion}

\section{The floras of the southern Bahia Restinga forests}

The species richness of the study areas were found to be similar to those of other Restinga forest surveys (Martins et al. 2008; Castro et al. 2012), but approximately three times lower than neighboring wet forest formations of the Atlantic domain (Amorim et al. 2008; Amorim et al. 2009). The low diversities of Restinga forests have been 

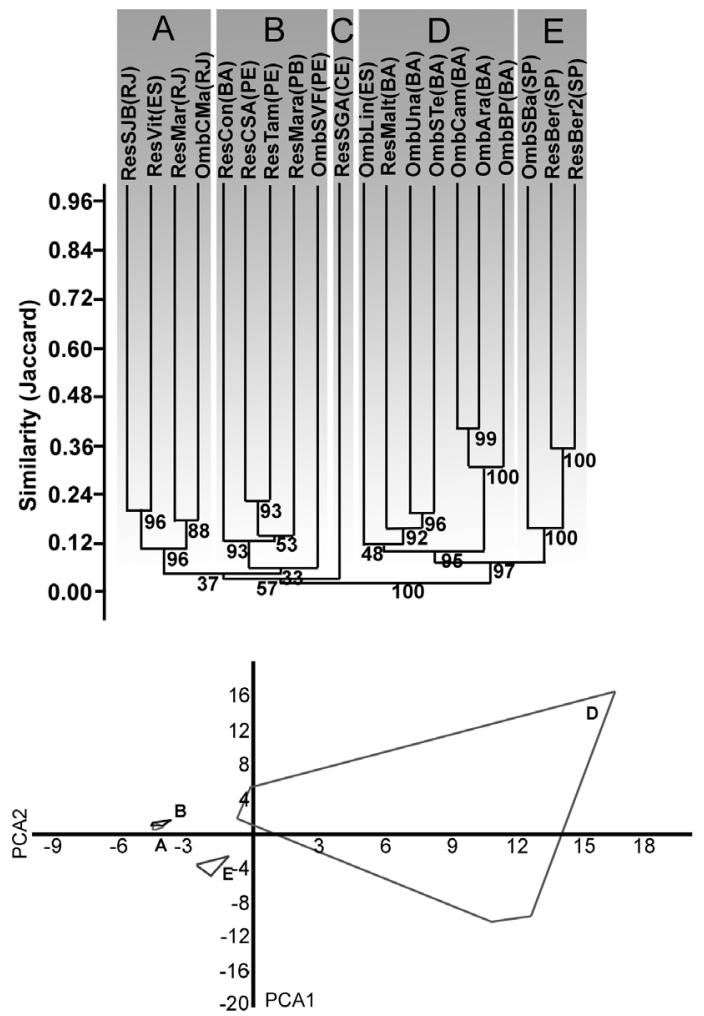

Figure 2-Results of the UPGMA cluster analysis that considered areas of Restinga and wet forests of the Atlantic domain (above), showing the formation of five major groups according to their Jaccard similarity indices. The numbers associated with the groups are bootstrap support values (1,000 replications). Principal component analysis (PCA) using the same 20 areas is indicated below, highlighting the four major groups (A, B, D and E) in the first two axes (34.4\% of total variance). The only area of group $C$ (São Gonçalo do Amarante, Ceará) is included within the polygons formed by groups A and B.

Figura 2 - Resultado da análise de agrupamento (UPGMA) entre áreas de florestas de Restinga e florestas pluviais do domínio Mata Atlântica (acima) mostrando a formação de cinco grupos principais de acordo com índice de similaridade de Jaccard. Números nos grupos são valores de suporte de bootstrap (1.000 replicações). Análise de componentes principais (PCA) entre as mesmas 20 áreas é mostrada abaixo ressaltando os quatro grupos maiores (A, B, D e E) nos dois primeiros eixos (34,4\% da variância total). A única área do grupo C (São Gonçalo do Amarante, Ceará) está incluída nos polígonos formados pelos grupos A e B.

highlighted by Guedes et al. (2006) and Lima et al. (2011), and seem to be determined by factors related to their nutrient-poor and well-drained sandy soils (Almeida Jr. et al. 2009). Edaphic conditions are therefore presumed to act as environmental filters that limit the establishment of lineages not adapted to the unique conditions of Restinga habitats.

The most species rich families encountered in our surveys (Fabaceae, Myrtaceae, Sapotaceae, and Rubiaceae) were also among the most important families reported in other Restinga forest sites (Assumpção \& Nascimento 2000; Assis et al. 2004; Martins et al. 2008; Silva et al. 2008). Myrtaceae taxa are typically found on soils with low fertility (Berry 1915) and are important components of Restinga vegetation along the entire coast of Brazil. Erythroxylaceae and Melastomataceae, on the other hand, generally contribute very few species to the Restinga forest floras, although they are well-represented in wet forests of the Atlantic domain (Stehmann et al. 2009); Erythroxylaceae also shows high richness in the Cerrado domain (Ratter et al. 2003). Bromeliaceae was among the five richest families in the Restinga forests studied. This family is highly diverse in eastern Brazil (Smith \& Downs 1979) and is the most diverse family of epiphytes in the Atlantic domain (Borgo \& Silva 2003; Giongo \& Weachter 2004) - but has relatively little importance in sites along the northern coast of Brazil (Castro et al. 2012). Thus, the high richness of families such Melastomataceae, Erythroxylaceae, and Bromeliaceae is probably idiosyncratic in southern Bahia Restinga forests.

Myrcia and Psychotria were among the most species rich genera in the study sites, and have likewise been reported as being highly diverse genera in Restinga forests (Martins et al. 2008) and other forest types in the Atlantic domain (Amorim et al. 2009; Stehmann et al. 2009). Aechmea, Erythroxylum, and Miconia were recorded here for the first time as being among the most diverse genera of Restinga forests.

Epiphytes are poorly represented in southern Bahia Restinga forests, in agreement with reports from coastal forests in the neighboring Espírito Santo State (Pereira et al. 1998).

The presence of species disjunct between Atlantic and Amazonian wet forests reinforces the hypothesis of past connections between these two forest blocks. It has been hypothesized that connections were possible during the wetter periods of the Quaternary due to the expansion of those wet forests and/or the emergence of ecological corridors (Bigarella \& Andrade-Lima 1982). About $8 \%$ of the species found in forests in southern Bahia have this distribution pattern (Mori et al. 
1981; Amorim et al. 2008), but less than 4\% of Restinga species in Rio de Janeiro State (Araújo 2000). These findings indicate that proximity to southern Bahia wet forests ("Hileia Baiana") accounts for higher proportions of species from Restinga forests in South Bahia showing AtlanticAmazonia disjunction patterns than those in other areas (Pereira \& Araújo 2000).

Some species encountered in the Restinga forests studied here occur from Atlantic domain forests through to the Caatinga and Cerrado domains, occasionally reaching the Amazon region. Oliveira-Filho \& Ratter (1995) concluded that these distribution patterns could have been established through two distinct processes: by interchanges of species between deciduous and semi-deciduous forests (requiring the presence of high to medium fertility soils); or the expansion of species from gallery forests (that could have acted as ecological corridors for wet forests trees across central Brazil).

Southern Bahia and northern Espírito Santo State show high levels of endemism and diversity (Thomas et al. 1998; Murray-Smith et al. 2008) - which has been attributed to the environmental stability of a putative ecological refuge during the climatic fluctuations of the Quaternary period (Carnaval \& Moritz 2008). The few endemic species observed in Restinga vegetation (Lima et al. 2011) probably reflect the more recent origin of its geological substrate (Scarano 2002).

Are Restinga forests a subset of Atlantic wet forests?

Multivariate analyzes demonstrated (with high bootstrap support) that Restinga forest sites did not group together, yielding instead mixed groups of Restinga forests and neighboring Atlantic wet forest sites. The Mantel test results reinforced the influence of geography on the similarities between areas, demonstrating that geographically closer areas tend to be more similar - even though they did not necessarily share similar ecological conditions (as with Restinga and wet forests).

The low similarity values observed are the result of only small numbers of species being shared between sites, and reflect the fact that different areas had floristic particularities that are probably the result of the environmental heterogeneity that characterizes Brazilian Restinga sites (Araújo \& Henriques 1984; Magnago et al. 2011).

The fact that Restinga forests: (1) have few endemic species; (2) are of recent geological origin; and (3) most species ( $\sim 94 \%$ ) also occur in wet forests in the Atlantic domain (Stehmann 2009), reinforce the hypothesis that Restingas are marginal habitats and that their floras are subsets of the floras of adjacent wet forest areas (Scarano 2009). These wet forests thus serve as sources of species able to overcome environmental filters imposed by unique restinga soil conditions (Assis et al. 2011). The proximity of wet forests that serve as sources of propagules should have strong influences on community assemblages and diversity patterns in Restinga forests (Assumpção \& Nascimento 2000; Almeida Jr et al. 2009; Santos et al. 2012). This floristic continuity, together with evidence that tropical forest trees can disperse pollen over long distances (up to $20 \mathrm{~km}$; see Ward et al. 2005 for a review), suggests that gene flow can occur between Restinga forest plants and populations in adjacent wet forests - and would account for low speciation rates and low endemism.

The Restinga forest sites of Bahia State clustered into two groups: 1) sites north of Todos os Santos Bay in group B and other sites from northeastern Brazil; and 2) sites in southern Bahia in group D and sites from northern Espírito Santo State. This finding reinforces previous reports that the Restinga vegetation of Bahia State forms two blocks - with sites located in the southern portion of that state being more similar to Restinga sites in Espírito Santo and Rio de Janeiro than to sites located in northern Bahia (Araújo 2000). The differentiation of these floristic blocks could reflect distinct climate types (a moist tropical climate with no dry season in the southern region, and a seasonal tropical climate with a dry winter in the northern region) (Peel et al. 2007; Alvares et al. 2013). Seasonality thus represents another factor that can influence the floristic composition of Restinga forests located north of Todos os Santo Bay, and this is corroborated by the presence of species that are typical of seasonal environments in group B sites, such as Commiphora leptophloeos (Mart.) J.B.Gillett (Burseraceae), Jatropha mollissima (Pohl) Baill. (Euphorbiaceae), and Syagrus coronata (Mart.) Becc (Arecaceae).

Substructuring according to elevation was noted in group D, with one group being formed by lowland areas ("tabuleiros") and Restinga, and another group formed by montane and submontane forests. Despite the environmental heterogeneity attributable to elevation, this group is well-supported (95\% bootstrap). Even though geographically distant, the inclusion of the Linhares area into this group was expected because of an apparent floristic 
gradient between the forests of northern Espírito Santo and those of southern Bahia State (OliveiraFilho \& Fontes 2000).

The areas located in the states of Rio de Janeiro and São Paulo formed two distinct groups by cluster analysis (groups A and E respectively). These two groups are located on the southeastern coast of Brazil (Villwock et al. 2005) an area that is characterized by the presence of the Serra do Mar mountain range. Coastal geology therefore also seems to influence the floristic composition of Restinga vegetation (Pereira \& Araújo 2000). Despite their geological affinities, groups $\mathrm{A}$ and E are subjected to different climatic regimes (Peel et al. 2007; Alvares et al. 2013), which justifies their separation.
The isolated position of the Restinga forest located in Ceará State reinforces the importance of contiguous vegetation areas as propagule sources in the constitution of Restinga forest floras. The Restinga forest in this area is close to Caatinga (dryland) vegetation and shares many species that predominantly occur in the latter, such as Cereus jamacaru DC. (Cactaceae), Croton blanchetianus Baill. (Euphorbiaceae), Margaritopsis carrascoana (Delprete \& E.B.Souza) C.M.Taylor \& E.B.Souza (Rubiaceae), and Sideroxylon obtusifolium (Humb. ex Roem. \& Schult.) T.D. Penn. (Sapotaceae).

\section{Supplementary material}

Supplementary material is available at $(<\mathrm{http}: / /$ dx.doi.org/10.6084/m9.figshare.1246794>).

Table 2 - List of the Angiosperm species collected at Maraú-Itacaré: MC= Mata do Caubi; MMI= Mata estrada Maraú-Itacaré; $\mathrm{MP}=$ Mata Piracanga; $\mathrm{MAS}=$ Mata do Santo Amaro. Brazilian phytogeographic domains: $\mathrm{AM}=\mathrm{Amazonian}$, $\mathrm{CA}=$ Caatinga, $\mathrm{CE}=$ Cerrado, $\mathrm{MA}=$ Atlantic Forest, $\mathrm{PAM}=$ Pampa, $\mathrm{PAN}=$ Pantanal. Collectors: EM= Eloína Neri de Matos; $\mathrm{MF}=$ Moabe Ferreira Fernandes. *= Species endemic to southeastern Bahia and northern Espírito Santo. Tabela 2 - Lista das espécies de Angiospermas amostradas nas florestas de Restinga da região de Maraú-Itacaré: MC= Mata do Caubi; $\mathrm{MMI}=$ Mata estrada Maraú-Itacaré; $\mathrm{MP}=$ Mata Piracanga; MAS= Mata do Santo Amaro. Domínios fitogeográficos: AM=Amazônia, $\mathrm{CA}=$ Caatinga, $\mathrm{CE}=$ Cerrado, $\mathrm{MA}=$ Mata Atlântica, $\mathrm{PAM}=$ Pampa, $\mathrm{PAN}=$ Pantanal. Coletores: $\mathrm{EM}=$ Eloína Neri de $\mathrm{Matos}$; $\mathrm{MF}=\mathrm{Moabe}$ Ferreira Fernandes. *=Endêmicas do sul da Bahia e norte do Espírito Santo.

\begin{tabular}{|c|c|c|c|c|c|c|c|}
\hline Family/Species & Habit & $\begin{array}{c}\text { Phytogeographic } \\
\text { domains }\end{array}$ & Voucher & MC & MMI & MP & MSA \\
\hline \multicolumn{8}{|l|}{ Acanthaceae } \\
\hline Aphelandra nitida Nees \& Mart. & Herb & MA & MF513 & $\mathrm{x}$ & $\mathrm{x}$ & $\mathrm{x}$ & $\mathrm{x}$ \\
\hline Ruellia affinis (Schrad.) Lindau* & Shrub & MA & MF130 & $\mathrm{x}$ & & & $\mathrm{x}$ \\
\hline \multicolumn{8}{|l|}{ Achariaceae } \\
\hline Carpotroche brasiliensis (Raddi) A Gray & Tree & CE, AM, MA & MF464 & & & & $\mathrm{x}$ \\
\hline \multicolumn{8}{|l|}{ Anacardiaceae } \\
\hline Tapirira guianensis Aubl. & Tree & $\mathrm{CA}, \mathrm{CE}, \mathrm{AM}, \mathrm{MA}$ & MF90 & $\mathrm{x}$ & $\mathrm{x}$ & $\mathrm{x}$ & $\mathrm{x}$ \\
\hline Thyrsodium spruceanum Benth. & Tree & $\mathrm{AM}, \mathrm{MA}$ & MF460 & & $\mathrm{x}$ & $\mathrm{x}$ & $x$ \\
\hline \multicolumn{8}{|l|}{ Annonaceae } \\
\hline Annona acutiflora Mart. & Tree & MA & MF540 & & $\mathrm{x}$ & $\mathrm{x}$ & \\
\hline $\begin{array}{l}\text { Annona bahiensis (Maas \& Westra) } \\
\text { H.Rainer }\end{array}$ & Tree & MA & MF541 & $\mathrm{x}$ & $\mathrm{x}$ & $\mathrm{x}$ & $\mathrm{x}$ \\
\hline Annona salzmannii A.DC. & Tree & MA & MF211 & $\mathrm{x}$ & $\mathrm{x}$ & $\mathrm{x}$ & $\mathrm{x}$ \\
\hline Duguetia restingae Maas* & Tree & MA & EM3535 & & & & $\mathrm{x}$ \\
\hline Guatteria australis A.St.-Hil. & Tree & MA & MF98 & $\mathrm{x}$ & $\mathrm{x}$ & $\mathrm{x}$ & $\mathrm{x}$ \\
\hline Guatteria oligocarpa Mart. & Tree & MA & MF152 & $\mathrm{x}$ & $\mathrm{x}$ & $\mathrm{x}$ & $\mathrm{x}$ \\
\hline
\end{tabular}




\begin{tabular}{|c|c|c|c|c|c|c|c|}
\hline Family/Species & Habit & $\begin{array}{c}\text { Phytogeographic } \\
\text { domains }\end{array}$ & Voucher & MC & MMI & MP & MSA \\
\hline Guatteria tomentosa Rusby & Tree & AM, MA & MF299 & $\mathrm{x}$ & & & $\mathrm{x}$ \\
\hline Unonopsis riedeliana R.E.Fr. & Tree & MA & MF317 & & & $\mathrm{x}$ & $\mathrm{x}$ \\
\hline Xylopia ochrantha Mart. & Tree & MA & MF420 & & & $\mathrm{x}$ & $\mathrm{x}$ \\
\hline Xylopia sericea A.St.-Hil. & Tree & CE, AM, MA & MF138 & & $\mathrm{x}$ & & \\
\hline Xylopia sp. & Tree & - & MF355 & & & $\mathrm{x}$ & \\
\hline \multicolumn{8}{|l|}{ Apocynaceae } \\
\hline Aspidosperma discolor A.DC. & Tree & CA, CE, AM, MA & MF270 & $\mathrm{x}$ & $\mathrm{x}$ & & $\mathrm{x}$ \\
\hline Couma rigida Müll.Arg.* & Tree & $\mathrm{CA}, \mathrm{MA}$ & MF283 & $\mathrm{x}$ & & $\mathrm{x}$ & \\
\hline Ditassa crassifolia Decne. & Vine & CE, MA & MF227 & $\mathrm{x}$ & $\mathrm{x}$ & $\mathrm{x}$ & \\
\hline Himatanthus bracteatus (A.DC.) Woodson & Tree & AM, MA & MF248 & & $\mathrm{x}$ & $\mathrm{x}$ & $\mathrm{x}$ \\
\hline $\begin{array}{l}\text { Mandevilla scabra (Hoffmanns. ex Roem. } \\
\text { \& Schult.) K.Schum. }\end{array}$ & Vine & CA, CE, AM, MA & MF79 & $\mathrm{x}$ & $\mathrm{x}$ & & \\
\hline Rauvolfia grandiflora Mart. & Tree & MA & MF122 & & & $\mathrm{x}$ & $\mathrm{x}$ \\
\hline $\begin{array}{l}\text { Tabernaemontana flavicans Willd. ex } \\
\text { Roem. \& Schult. }\end{array}$ & Tree & CE, AM, MA & MF364 & & $\mathrm{x}$ & & $\mathrm{x}$ \\
\hline Tabernaemontana salzmannii A.DC. & Tree & CE, MA & MF112 & & & & $\mathrm{x}$ \\
\hline \multicolumn{8}{|l|}{ Aquifoliaceae } \\
\hline Ilex floribunda Reissek ex Maxim. & Tree & MA & MF430 & $\mathrm{x}$ & $\mathrm{x}$ & $\mathrm{x}$ & $\mathrm{x}$ \\
\hline \multicolumn{8}{|l|}{ Araceae } \\
\hline Anthurium gladiifolium Schott & Herb & MA & MF345 & & & & $\mathrm{x}$ \\
\hline Heteropsis oblongifolia Kunth & Herb & $\mathrm{CE}, \mathrm{AM}, \mathrm{MA}$ & MF91 & $\mathrm{x}$ & $\mathrm{x}$ & $\mathrm{x}$ & $\mathrm{x}$ \\
\hline Rhodospatha latifolia Poepp. & Herb & CA, CE, AM, MA & EM3543 & & & & $\mathrm{x}$ \\
\hline \multicolumn{8}{|l|}{ Araliaceae } \\
\hline $\begin{array}{l}\text { Schefflera selloi (Marchal) Frodin \& } \\
\text { Fiaschi* }\end{array}$ & Tree & MA & MF261 & $\mathrm{x}$ & $\mathrm{x}$ & $\mathrm{x}$ & \\
\hline \multicolumn{8}{|l|}{ Arecaceae } \\
\hline Attalea funifera Mart. ex Spreng. & Tree & MA & MF542 & $\mathrm{x}$ & $\mathrm{x}$ & $\mathrm{x}$ & $\mathrm{x}$ \\
\hline Bactris hirta Mart. & Shrub & AM, MA & MF408 & & $\mathrm{x}$ & $\mathrm{x}$ & \\
\hline $\begin{array}{l}\text { Bactris horridispatha Noblick ex } \\
\text { A.J.Hend.* }\end{array}$ & Shrub & MA & MF343 & $\mathrm{x}$ & & & $\mathrm{x}$ \\
\hline Euterpe edulis Mart. & Tree & CE, MA & MF543 & $\mathrm{x}$ & $\mathrm{x}$ & $\mathrm{x}$ & $\mathrm{x}$ \\
\hline Geonoma pauciflora Mart. & Shrub & MA & EM3536 & & & $\mathrm{x}$ & \\
\hline Geonoma pohliana Mart. & Shrub & MA & MF292 & & $\mathrm{x}$ & & \\
\hline \multicolumn{8}{|l|}{ Asteraceae } \\
\hline Piptocarpha riedelii (Sch.Bip.) Baker* & Vine & MA & MF479 & $\mathrm{x}$ & $\mathrm{x}$ & & \\
\hline $\begin{array}{l}\text { Vernonanthura divaricata (Spreng.) } \\
\text { H.Rob. }\end{array}$ & Shrub & CE, MA & MF417 & $\mathrm{x}$ & & & $\mathrm{x}$ \\
\hline Vernonanthura vinhae (H.Rob.) H.Rob.* & Shrub & MA & MF213 & $\mathrm{x}$ & $\mathrm{x}$ & $\mathrm{x}$ & \\
\hline
\end{tabular}




\begin{tabular}{|c|c|c|c|c|c|c|c|}
\hline Family/Species & Habit & $\begin{array}{c}\text { Phytogeographic } \\
\text { domains }\end{array}$ & Voucher & MC & MMI & MP & MSA \\
\hline \multicolumn{8}{|l|}{ Bignoniaceae } \\
\hline $\begin{array}{l}\text { Anemopaegma chamberlaynii (Sims) } \\
\text { Bureau \& K.Schum. }\end{array}$ & Vine & $\mathrm{CA}, \mathrm{CE}, \mathrm{MA}$ & MF140 & & $\mathrm{x}$ & & $\mathrm{x}$ \\
\hline Handroanthus umbellatus (Sond.) Mattos & Tree & $\mathrm{CA}, \mathrm{CE}, \mathrm{MA}$ & MF390 & & $\mathrm{x}$ & & $\mathrm{x}$ \\
\hline Jacaranda obovata Cham. & Tree & $\mathrm{CA}, \mathrm{CE}, \mathrm{MA}$ & MF500 & $\mathrm{x}$ & $\mathrm{x}$ & $\mathrm{x}$ & $\mathrm{x}$ \\
\hline Lundia cordata (Vell.) DC. & Vine & $\mathrm{CA}, \mathrm{MA}$ & MF95 & $\mathrm{x}$ & & & $\mathrm{x}$ \\
\hline Tabebuia elliptica (DC.) Sandwith & Tree & $\mathrm{CA}, \mathrm{CE}, \mathrm{MA}$ & MF77 & $\mathrm{x}$ & $\mathrm{x}$ & $\mathrm{x}$ & $\mathrm{x}$ \\
\hline Tabebuia stenocalyx Sprague \& Stapf & Tree & MA & MF74 & $\mathrm{x}$ & $\mathrm{x}$ & $\mathrm{x}$ & $\mathrm{x}$ \\
\hline \multicolumn{8}{|l|}{ Boraginaceae } \\
\hline Cordia glabrifolia M.Stapf* & Tree & MA & EM3554 & & & & $\mathrm{x}$ \\
\hline \multicolumn{8}{|l|}{ Bromeliaceae } \\
\hline Aechmea amorimii Leme* & Epiphyte & MA & MF357 & & & & $\mathrm{x}$ \\
\hline Aechmea andersonii H.Luther \& Leme* & Epiphyte & MA & EM3534 & & & & $\mathrm{x}$ \\
\hline Aechmea aquilega (Salisb.) Griseb. & Herb & $\mathrm{CA}, \mathrm{CE}, \mathrm{AM}, \mathrm{MA}$ & EM3540 & $\mathrm{x}$ & $\mathrm{x}$ & & \\
\hline Aechmea bicolor L.B.Sm.* & Epiphyte & MA & MF296 & & & & $\mathrm{x}$ \\
\hline Aechmea blanchetiana (Baker) L.B.Sm.* & Herb & MA & MF134 & $\mathrm{x}$ & $\mathrm{x}$ & $\mathrm{x}$ & \\
\hline Aechmea bromeliifolia (Rudge) Baker & Herb & $\mathrm{CA}, \mathrm{CE}, \mathrm{AM}, \mathrm{MA}$ & MF133 & $\mathrm{x}$ & $\mathrm{x}$ & & $\mathrm{x}$ \\
\hline Aechmea marauensis Leme & Herb & MA & MF110 & & & $\mathrm{x}$ & $\mathrm{x}$ \\
\hline $\begin{array}{l}\text { Aechmea mertensii (G.Mey.) Schult. \& } \\
\text { Schult.f. }\end{array}$ & Epiphyte & AM, MA & MF450 & & & & $\mathrm{x}$ \\
\hline Guzmania lingulata (L.) Mez & Epiphyte & AM, MA & EM3537 & $\mathrm{x}$ & $\mathrm{x}$ & $\mathrm{x}$ & $\mathrm{x}$ \\
\hline Vriesea duvaliana E.Morren* & Epiphyte & MA & EM3544 & & & $\mathrm{x}$ & \\
\hline Vriesea ensiformis (Vell.) Beer & Epiphyte & MA & EM3552 & & & $\mathrm{x}$ & \\
\hline $\begin{array}{l}\text { Vriesea procera (Mart. ex Schult. \& } \\
\text { Schult.f.) Wittm. }\end{array}$ & Herb & $\mathrm{CA}, \mathrm{CE}, \mathrm{MA}$ & MF224 & $\mathrm{x}$ & $\mathrm{x}$ & $\mathrm{x}$ & \\
\hline \multicolumn{8}{|l|}{ Burseraceae } \\
\hline Protium bahianum Daly* & Tree & MA & MF478 & & $\mathrm{x}$ & $\mathrm{x}$ & $\mathrm{x}$ \\
\hline Protium heptaphyllum (Aubl.) Marchand & Tree & $\mathrm{CA}, \mathrm{CE}, \mathrm{AM}, \mathrm{MA}$ & MF359 & $\mathrm{x}$ & $\mathrm{x}$ & $\mathrm{x}$ & $\mathrm{x}$ \\
\hline Tetragastris occhionii (Rizzini) Daly* & Tree & MA & MF318 & & & $\mathrm{x}$ & $\mathrm{x}$ \\
\hline \multicolumn{8}{|l|}{ Callophylaceae } \\
\hline Kielmeyera itacarensis Saddi * & Tree & MA & MF537 & $\mathrm{x}$ & & & \\
\hline \multicolumn{8}{|l|}{ Cannabaceae } \\
\hline Trema micrantha (L.) Blume & Tree & $\begin{array}{l}\text { AM, CA, CE, MA, } \\
\text { PAN, PAM }\end{array}$ & MF358 & & & & $\mathrm{x}$ \\
\hline \multicolumn{8}{|l|}{ Caricaceae } \\
\hline Jacaratia heptaphylla (Vell.) A.DC. & Tree & MA & MF83 & $\mathrm{x}$ & & $\mathrm{x}$ & $\mathrm{x}$ \\
\hline Caryocaraceae & & & & & & & \\
\hline
\end{tabular}




\begin{tabular}{|c|c|c|c|c|c|c|c|}
\hline Family/Species & Habit & $\begin{array}{c}\text { Phytogeographic } \\
\text { domains }\end{array}$ & Voucher & MC & MMI & MP & MSA \\
\hline $\begin{array}{l}\text { Anthodiscus amazonicus Gleason \& } \\
\text { A.C.Sm. }\end{array}$ & Tree & AM, MA & MF342 & & $\mathrm{x}$ & & $\mathrm{x}$ \\
\hline \multicolumn{8}{|l|}{ Celastraceae } \\
\hline Maytenus distichophylla Mart. ex Reissek & Tree & MA & MF256 & $\mathrm{x}$ & $\mathrm{x}$ & $\mathrm{x}$ & $\mathrm{x}$ \\
\hline \multicolumn{8}{|l|}{ Chrysobalanaceae } \\
\hline Couepia belemii Prance* & Tree & MA & MF129 & $\mathrm{x}$ & $\mathrm{x}$ & $\mathrm{x}$ & $\mathrm{x}$ \\
\hline $\begin{array}{l}\text { Couepia ovalifolia (Schott) Benth. ex } \\
\text { Hook.f. }\end{array}$ & Tree & CE, MA & MF223 & & $\mathrm{x}$ & $\mathrm{x}$ & \\
\hline Licania hoehnei Pilg. & Tree & CE, MA & MF531 & $\mathrm{x}$ & & & $\mathrm{x}$ \\
\hline Licania hypoleuca Benth. & Tree & AM, MA & MF454 & $\mathrm{x}$ & $\mathrm{x}$ & $\mathrm{x}$ & $\mathrm{x}$ \\
\hline Licania lamentanda Prance* & Tree & MA & EM3553 & & & & $\mathrm{x}$ \\
\hline Licania littoralis Warm. & Tree & MA & EM3559 & & & & $\mathrm{x}$ \\
\hline Licania sp. & Tree & - & MF356 & & $\mathrm{x}$ & & \\
\hline Parinari alvimii Prance* & Tree & MA & MF240 & & & $\mathrm{x}$ & \\
\hline \multicolumn{8}{|l|}{ Clusiaceae } \\
\hline Clusia nemorosa G.Mey. & Tree & CA, CE, AM, MA & MF415 & $\mathrm{x}$ & $\mathrm{x}$ & $\mathrm{x}$ & $\mathrm{x}$ \\
\hline Clusia sellowiana Schltdl. & Tree & MA & MF491 & & & $\mathrm{x}$ & $\mathrm{x}$ \\
\hline $\begin{array}{l}\text { Garcinia gardneriana (Planch. \& Triana) } \\
\text { Zappi }\end{array}$ & Tree & CA, CE, AM, MA & MF305 & $\mathrm{x}$ & $\mathrm{x}$ & $\mathrm{x}$ & $\mathrm{x}$ \\
\hline Garcinia macrophylla Mart. & Tree & AM, MA & MF333 & $\mathrm{x}$ & & & \\
\hline Symphonia globulifera L.f. & Tree & AM, MA & MF281 & $\mathrm{x}$ & $\mathrm{x}$ & $\mathrm{x}$ & $\mathrm{x}$ \\
\hline \multicolumn{8}{|l|}{ Combretaceae } \\
\hline Buchenavia hoehneana N.F.Mattos & Tree & MA & MF389 & & $\mathrm{x}$ & & $\mathrm{x}$ \\
\hline Conocarpus erectus L. & Tree & AM, MA & MF243 & & & & $\mathrm{x}$ \\
\hline Terminalia glabrescens Mart. & Tree & $\mathrm{CA}, \mathrm{CE}, \mathrm{AM}, \mathrm{MA}$ & MF353 & $\mathrm{x}$ & $\mathrm{x}$ & $\mathrm{x}$ & $\mathrm{x}$ \\
\hline \multicolumn{8}{|l|}{ Comelinaceae } \\
\hline $\begin{array}{l}\text { Dichorisandra procera Mart. ex Schult } \\
\text { \& Schult.f. }\end{array}$ & Herb & MA & MF286 & $\mathrm{x}$ & $\mathrm{x}$ & $\mathrm{x}$ & $\mathrm{x}$ \\
\hline \multicolumn{8}{|l|}{ Cucurbitaceae } \\
\hline Cayaponia petiolulata Cogn.* & Vine & MA & MF 103 & & & & $\mathrm{x}$ \\
\hline Gurania lobata (L.) Pruski & Vine & AM, MA & MF398 & $\mathrm{x}$ & & $\mathrm{x}$ & $\mathrm{x}$ \\
\hline \multicolumn{8}{|l|}{ Cyclanthaceae } \\
\hline Evodianthus funifer (Poit.) Lindm. & Herb & AM, MA & MF105 & $\mathrm{x}$ & $\mathrm{x}$ & $\mathrm{x}$ & $\mathrm{x}$ \\
\hline \multicolumn{8}{|l|}{ Dichapetalaceae } \\
\hline Tapura sp. & Tree & - & MF336 & & & $\mathrm{x}$ & \\
\hline \multicolumn{8}{|l|}{ Dilleniaceae } \\
\hline Davilla flexuosa A.St.-Hil. & Vine & MA & MF477 & $\mathrm{x}$ & $\mathrm{x}$ & $\mathrm{x}$ & $\mathrm{x}$ \\
\hline
\end{tabular}




\begin{tabular}{|c|c|c|c|c|c|c|c|}
\hline Family/Species & Habit & $\begin{array}{c}\text { Phytogeographic } \\
\text { domains }\end{array}$ & Voucher & MC & MMI & MP & MSA \\
\hline Doliocarpus validus Kubitzki* & Vine & MA & MF360 & & $\mathrm{x}$ & & $\mathrm{x}$ \\
\hline \multicolumn{8}{|l|}{ Elaeocarpaceae } \\
\hline Sloanea guianensis (Aubl.) Benth. & Tree & $\mathrm{CE}, \mathrm{AM}, \mathrm{MA}$ & MF285 & $\mathrm{x}$ & $\mathrm{x}$ & & \\
\hline \multicolumn{8}{|l|}{ Ericaceae } \\
\hline $\begin{array}{l}\text { Agarista revoluta (Spreng.) J.D. Hook. } \\
\text { ex Nied. }\end{array}$ & Shrub & MA & MF380 & $\mathrm{x}$ & $\mathrm{x}$ & & $\mathrm{x}$ \\
\hline \multicolumn{8}{|l|}{ Erythroxylaceae } \\
\hline Erythroxylum compressum Peyr.* & Shrub & MA & MF216 & & & & $\mathrm{x}$ \\
\hline Erythroxylum cuspidifolium Mart. & Tree & MA & EM3562 & & & & $\mathrm{x}$ \\
\hline Erythroxylum martii Peyr.* & Shrub & MA & MF73 & $\mathrm{x}$ & $\mathrm{x}$ & & \\
\hline Erythroxylum mattos-silvae Plowman* & Tree & MA & MF344 & $\mathrm{x}$ & $\mathrm{x}$ & $\mathrm{x}$ & \\
\hline Erythroxylum mikanii Peyr. & Shrub & MA & EM3545 & & & $\mathrm{x}$ & \\
\hline Erythroxylum nobile O.E.Schulz & Tree & MA & EM3567 & & $\mathrm{x}$ & & \\
\hline Erythroxylum passerinum Mart. & Tree & MA & EM3539 & $\mathrm{x}$ & $\mathrm{x}$ & & \\
\hline Erythroxylum splendidum Plowman* & Tree & MA & MF78 & $\mathrm{x}$ & & & $\mathrm{x}$ \\
\hline Erythroxylum squamatum Sw. & Tree & $\mathrm{CA}, \mathrm{CE}, \mathrm{AM}, \mathrm{MA}$ & MF87 & $\mathrm{x}$ & & & \\
\hline Erythroxylum tenue Plowman* & Shrub & MA & MF320 & $\mathrm{x}$ & $\mathrm{x}$ & & \\
\hline \multicolumn{8}{|l|}{ Euphorbiaceae } \\
\hline $\begin{array}{l}\text { Actinostemon concolor (Spreng.) Müll. } \\
\text { Arg. }\end{array}$ & Tree & $\mathrm{CA}, \mathrm{CE}, \mathrm{AM}, \mathrm{MA}$ & MF372 & & & $\mathrm{x}$ & $\mathrm{x}$ \\
\hline $\begin{array}{l}\text { Alchornea glandulosa subsp. iricurana } \\
\text { (Casar.) Secco }\end{array}$ & Tree & MA & MF298 & $\mathrm{x}$ & & & \\
\hline Astraea sp. & Tree & - & MF225 & & $\mathrm{x}$ & $\mathrm{x}$ & \\
\hline Croton macrobothrys Baill. & Tree & MA & MF447 & & $\mathrm{x}$ & $\mathrm{x}$ & \\
\hline Croton sellowii Baill. & Shrub & $\mathrm{CA}, \mathrm{MA}$ & MF271 & $\mathrm{x}$ & $\mathrm{x}$ & $\mathrm{x}$ & $\mathrm{x}$ \\
\hline Microstachys corniculata (Vahl) Griseb. & Herb & $\mathrm{CA}, \mathrm{CE}, \mathrm{AM}, \mathrm{MA}$ & MF350 & $\mathrm{x}$ & & & \\
\hline $\begin{array}{l}\text { Microstachys heterodoxa (Müll.Arg.) } \\
\text { Esser* }\end{array}$ & Shrub & $\mathrm{CA}, \mathrm{MA}$ & MF379 & & $\mathrm{x}$ & & \\
\hline \multicolumn{8}{|l|}{ Fabaceae } \\
\hline Abarema filamentosa (Benth.) Pittier & Tree & MA & MF88 & $\mathrm{x}$ & $\mathrm{x}$ & $\mathrm{x}$ & $\mathrm{x}$ \\
\hline Abarema jupunba (Willd.) Britton \& Killip & Tree & AM, MA & MF93 & & & $\mathrm{x}$ & $\mathrm{x}$ \\
\hline $\begin{array}{l}\text { Abarema turbinata (Benth.) Barneby \& } \\
\text { J.W.Grimes* }\end{array}$ & Tree & MA & MF104 & $\mathrm{x}$ & $\mathrm{x}$ & $\mathrm{x}$ & \\
\hline Albizia pedicellaris (DC.) L.Rico & Tree & $\mathrm{CE}, \mathrm{AM}, \mathrm{MA}$ & MF113 & & & & $\mathrm{x}$ \\
\hline Andira marauensis N.F.Mattos* & Tree & MA & MF76 & & $\mathrm{x}$ & $\mathrm{x}$ & \\
\hline Andira nitida Mart. ex Benth. & Tree & MA & MF323 & $\mathrm{x}$ & $\mathrm{x}$ & $\mathrm{x}$ & $\mathrm{x}$ \\
\hline Arapatiella psilophylla (Harms) R.S.Cowan* & Tree & MA & MF128 & & & & $\mathrm{x}$ \\
\hline
\end{tabular}




\begin{tabular}{|c|c|c|c|c|c|c|c|}
\hline Family/Species & Habit & $\begin{array}{c}\text { Phytogeographic } \\
\text { domains }\end{array}$ & Voucher & MC & MMI & MP & MSA \\
\hline $\begin{array}{l}\text { Chamaecrista ensiformis (Vell.) H.S.Irwin } \\
\text { \& Barneby }\end{array}$ & Tree & $\mathrm{CA}, \mathrm{CE}, \mathrm{AM}, \mathrm{MA}$ & MF157 & & & & $\mathrm{x}$ \\
\hline Clitoria falcata Lam. & Vine & CE, AM, MA & MF337 & & $\mathrm{x}$ & & $\mathrm{x}$ \\
\hline Copaifera lucens Dwyer & Tree & MA & MF384 & & & & $\mathrm{x}$ \\
\hline Dalbergia nigra (Vell.) Allemão ex Benth. & Tree & MA & MF403 & & & & $\mathrm{x}$ \\
\hline Diplotropis incexis Rizzini \& A.Mattos & Tree & MA & MF228 & $\mathrm{x}$ & $\mathrm{x}$ & $\mathrm{x}$ & \\
\hline Harleyodendron unifoliolatum R.S.Cowan & Tree & MA & MF468 & & & & $\mathrm{x}$ \\
\hline Hymenolobium alagoanum Ducke & Tree & MA & MF141 & $\mathrm{x}$ & $\mathrm{x}$ & & \\
\hline Inga capitata Desv. & Tree & AM, MA & MF99 & $\mathrm{x}$ & $\mathrm{x}$ & $\mathrm{x}$ & $\mathrm{x}$ \\
\hline Inga edulis Mart. & Tree & CA, CE, AM, MA & MF348 & & $\mathrm{x}$ & & $\mathrm{x}$ \\
\hline Inga pleiogyna T.D.Penn.* & Tree & MA & MF151 & $\mathrm{x}$ & $\mathrm{x}$ & & $\mathrm{x}$ \\
\hline Inga tenuis (Vell.) Mart. & Tree & MA & MF392 & $\mathrm{x}$ & & $\mathrm{x}$ & $\mathrm{x}$ \\
\hline Inga thibaudiana DC. & Tree & CA, CE, AM, MA & MF86 & $\mathrm{x}$ & & & $\mathrm{x}$ \\
\hline Leptolobium bijugum (Spreng.) Vogel & Tree & MA & MF275 & $\mathrm{x}$ & & & \\
\hline Machaerium salzmannii Benth. & Shrub & MA & MF102 & & & & $\mathrm{x}$ \\
\hline Macrolobium latifolium Vogel* & Tree & MA & MF101 & $\mathrm{x}$ & $\mathrm{x}$ & & $\mathrm{x}$ \\
\hline Mimosa ceratonia $\mathrm{L}$. & Vine & CE, MA & MF207 & & & & $\mathrm{x}$ \\
\hline Moldenhawera blanchetiana Tul.* & Tree & MA & MF162 & & & & $\mathrm{x}$ \\
\hline Ormosia fastigiata Tul. & Tree & CE, MA & MF255 & $\mathrm{x}$ & $\mathrm{x}$ & $\mathrm{x}$ & $\mathrm{x}$ \\
\hline Parkia bahiae H.C.Hopkins* & Tree & MA & MF81 & $\mathrm{x}$ & $\mathrm{x}$ & $\mathrm{x}$ & $\mathrm{x}$ \\
\hline Parkia pendula (Willd.) Benth. ex Walp. & Tree & AM, MA & MF206 & & & $\mathrm{x}$ & $\mathrm{x}$ \\
\hline $\begin{array}{l}\text { Piptadenia adiantoides (Spreng.) } \\
\text { J.F.Macbr. }\end{array}$ & Vine & CA, CE, MA & MF125 & & & & $\mathrm{x}$ \\
\hline Pterocarpus rohrii Vahl & Tree & CE, AM, MA & MF385 & & $\mathrm{x}$ & $\mathrm{x}$ & \\
\hline Senna pinheiroi H.S.Irwin \& Barneby & Shrub & $\mathrm{CA}, \mathrm{MA}$ & MF144 & $\mathrm{x}$ & & & $\mathrm{x}$ \\
\hline Swartzia apetala Raddi & Tree & CA, CE, MA & MF80 & $\mathrm{x}$ & & $\mathrm{x}$ & $\mathrm{x}$ \\
\hline Swartzia polita (R.S.Cowan) Torke* & Tree & MA & MF302 & $\mathrm{x}$ & $\mathrm{x}$ & $\mathrm{x}$ & $\mathrm{x}$ \\
\hline Swartzia simplex (Sw.) Spreng. & Tree & MA & MF346 & $\mathrm{x}$ & $\mathrm{x}$ & & \\
\hline $\begin{array}{l}\text { Tachigali densiflora (Benth.) L.G.Silva } \\
\& \text { H.C.Lima }\end{array}$ & Tree & MA & MF282 & $\mathrm{x}$ & & & $\mathrm{x}$ \\
\hline Zollernia glabra (Spreng.) Yakovlev & Tree & MA & MF273 & $\mathrm{x}$ & $\mathrm{x}$ & $\mathrm{x}$ & \\
\hline \multicolumn{8}{|l|}{ Gentianaceae } \\
\hline $\begin{array}{l}\text { Chelonanthus purpurascens (Aubl.) } \\
\text { Struwe et al. }\end{array}$ & Herb & $\mathrm{CA}, \mathrm{CE}, \mathrm{AM}, \mathrm{MA}$ & MF118 & & & & $\mathrm{x}$ \\
\hline \multicolumn{8}{|l|}{ Heliconiaceae } \\
\hline Heliconia psittacorum L.f. & Herb & $\begin{array}{l}\text { AM, CA, CE, MA, } \\
\text { PAN }\end{array}$ & EM3566 & & & & $\mathrm{x}$ \\
\hline Humiriaceae & & & & & & & \\
\hline
\end{tabular}




\begin{tabular}{|c|c|c|c|c|c|c|c|}
\hline Family/Species & Habit & $\begin{array}{c}\text { Phytogeographic } \\
\text { domains }\end{array}$ & Voucher & MC & MMI & MP & MSA \\
\hline Humiria balsamifera (Aubl.) J.St.-Hil. & Tree & $\mathrm{CA}, \mathrm{CE}, \mathrm{AM}, \mathrm{MA}$ & MF136 & $\mathrm{x}$ & $\mathrm{x}$ & $\mathrm{x}$ & $\mathrm{x}$ \\
\hline Sacoglottis mattogrossensis Malme & Tree & $\mathrm{CE}, \mathrm{AM}, \mathrm{MA}$ & MF485 & $\mathrm{x}$ & & & \\
\hline Vantanea bahiaensis Cuatrec.* & Tree & MA & MF301 & & $\mathrm{x}$ & & \\
\hline \multicolumn{8}{|l|}{ Hypericaceae } \\
\hline Vismia guianensis (Aubl.) Choisy & Tree & $\mathrm{CA}, \mathrm{CE}, \mathrm{AM}, \mathrm{MA}$ & MF100 & $\mathrm{x}$ & $\mathrm{x}$ & $\mathrm{x}$ & $\mathrm{x}$ \\
\hline Vismia macrophylla Kunth & Tree & AM, MA & MF149 & & & & $\mathrm{x}$ \\
\hline \multicolumn{8}{|l|}{ Icacinaceae } \\
\hline Emmotum affine Miers & Tree & MA & MF316 & $\mathrm{x}$ & $\mathrm{x}$ & $\mathrm{x}$ & $\mathrm{x}$ \\
\hline \multicolumn{8}{|l|}{ Lacistemataceae } \\
\hline Lacistema robustum Schnizl. & Tree & MA & MF117 & $\mathrm{x}$ & & & $\mathrm{x}$ \\
\hline \multicolumn{8}{|l|}{ Lamiaceae } \\
\hline Aegiphila integrifolia (Jacq.) Moldenke & Vine & $\mathrm{CA}, \mathrm{CE}, \mathrm{AM}, \mathrm{MA}$ & MF470 & & $\mathrm{x}$ & & \\
\hline Aegiphila macrantha Ducke & Vine & AM, MA & MF525 & & & & $\mathrm{x}$ \\
\hline Vitex polygama Cham. & Tree & $\mathrm{CA}, \mathrm{CE}, \mathrm{AM}, \mathrm{MA}$ & MF242 & $\mathrm{x}$ & $\mathrm{x}$ & $\mathrm{x}$ & \\
\hline \multicolumn{8}{|l|}{ Lauraceae } \\
\hline Endlicheria glomerata $\mathrm{Mez}$ & Tree & $\mathrm{CA}, \mathrm{CE}, \mathrm{MA}$ & MF544 & $\mathrm{x}$ & & & \\
\hline Nectandra membranacea (Sw.) Griseb. & Tree & $\mathrm{CA}, \mathrm{CE}, \mathrm{AM}, \mathrm{MA}$ & MF352 & $\mathrm{x}$ & $\mathrm{x}$ & & \\
\hline Ocotea canaliculata ( Rich.) Mez & Tree & AM, MA & MF276 & $\mathrm{x}$ & & & \\
\hline Ocotea notata (Nees \& Mart.) Mez & Tree & MA & MF326 & $\mathrm{x}$ & $\mathrm{x}$ & $\mathrm{x}$ & $\mathrm{x}$ \\
\hline Ocotea nutans (Nees) Mez & Tree & $\mathrm{CE}, \mathrm{MA}$ & MF295 & $\mathrm{x}$ & & $\mathrm{x}$ & \\
\hline Persea caesia Meisn. & Tree & MA & MF309 & & $\mathrm{x}$ & & \\
\hline \multicolumn{8}{|l|}{ Lecythidaceae } \\
\hline $\begin{array}{l}\text { Eschweilera ovata (Cambess.) Mart. ex } \\
\text { Miers }\end{array}$ & Tree & $\mathrm{CA}, \mathrm{CE}, \mathrm{AM}, \mathrm{MA}$ & MF165 & $\mathrm{x}$ & $\mathrm{x}$ & $\mathrm{x}$ & $\mathrm{x}$ \\
\hline Lecythis lurida (Miers) S.A.Mori & Tree & $\mathrm{AM}, \mathrm{MA}$ & MF373 & & & $\mathrm{x}$ & \\
\hline Lecythis pisonis Cambess. & Tree & AM, MA & MF394 & & & & $\mathrm{x}$ \\
\hline \multicolumn{8}{|l|}{ Malpighiaceae } \\
\hline Byrsonima cacaophila W.R.Anderson* & Tree & MA & MF289 & & $\mathrm{x}$ & & $\mathrm{x}$ \\
\hline Byrsonima sericea DC. & Tree & $\mathrm{CA}, \mathrm{CE}, \mathrm{MA}$ & MF250 & $\mathrm{x}$ & $\mathrm{x}$ & $\mathrm{x}$ & $\mathrm{x}$ \\
\hline Heteropterys imperata Amorim* & Vine & MA & MF347 & $\mathrm{x}$ & & $\mathrm{x}$ & $\mathrm{x}$ \\
\hline Stigmaphyllon blanchetii C.E.Anderson & Vine & $\mathrm{CA}, \mathrm{CE}, \mathrm{MA}$ & MF147 & & $\mathrm{x}$ & & $\mathrm{x}$ \\
\hline \multicolumn{8}{|l|}{ Malvaceae } \\
\hline Apeiba tibourbou Aubl. & Tree & $\mathrm{CA}, \mathrm{CE}, \mathrm{AM}, \mathrm{MA}$ & MF121 & & & & $\mathrm{x}$ \\
\hline $\begin{array}{l}\text { Eriotheca macrophylla (K.Schum.) } \\
\text { A.Robyns }\end{array}$ & Tree & MA & MF510 & $\mathrm{x}$ & $\mathrm{x}$ & $\mathrm{x}$ & $\mathrm{x}$ \\
\hline Melastomataceae & & & & & & & \\
\hline
\end{tabular}




\begin{tabular}{|c|c|c|c|c|c|c|c|}
\hline Family/Species & Habit & $\begin{array}{c}\text { Phytogeographic } \\
\text { domains }\end{array}$ & Voucher & MC & MMI & MP & MSA \\
\hline Henriettea succosa (Aubl.) DC. & Tree & AM, MA & MF123 & $\mathrm{x}$ & $\mathrm{x}$ & & $\mathrm{x}$ \\
\hline Miconia albicans (Sw.) Triana & Shrub & $\mathrm{CA}, \mathrm{CE}, \mathrm{AM}, \mathrm{MA}$ & MF509 & & $\mathrm{x}$ & & \\
\hline Miconia amoena Triana & Tree & MA & MF215 & & & $\mathrm{x}$ & $\mathrm{x}$ \\
\hline Miconia ciliata (Rich.) DC. & Tree & CA, CE, AM, MA & MF114 & $\mathrm{x}$ & & & \\
\hline Miconia cinnamomifolia (DC.) Naudin & Tree & MA & MF461 & $\mathrm{x}$ & $\mathrm{x}$ & & $\mathrm{x}$ \\
\hline Miconia compressa Naudin & Shrub & MA & MF108 & & $\mathrm{x}$ & $\mathrm{x}$ & $\mathrm{x}$ \\
\hline Miconia holosericea (L.) DC. & Tree & CE, AM, MA & MF418 & $\mathrm{x}$ & $\mathrm{x}$ & & \\
\hline Miconia prasina (Sw.) DC. & Tree & $\mathrm{CA}, \mathrm{CE}, \mathrm{AM}, \mathrm{MA}$ & MF458 & $\mathrm{x}$ & & & $\mathrm{x}$ \\
\hline Miconia tomentosa (Rich.) D.Don & Tree & CE, AM, MA & MF284 & & & & $\mathrm{x}$ \\
\hline \multicolumn{8}{|l|}{ Meliaceae } \\
\hline Guarea guidonia (L.) Sleumer & Tree & CA, CE, AM, MA & MF322 & $\mathrm{x}$ & $\mathrm{x}$ & $\mathrm{x}$ & $\mathrm{x}$ \\
\hline Trichilia lepidota Mart. & Tree & MA & MF232 & $\mathrm{x}$ & $\mathrm{x}$ & $\mathrm{x}$ & $\mathrm{x}$ \\
\hline Trichilia ramalhoi Rizzini & Tree & MA & MF145 & & & $\mathrm{x}$ & $\mathrm{x}$ \\
\hline \multicolumn{8}{|l|}{ Moraceae } \\
\hline Brosimum rubescens Taub. & Tree & AM, MA & EM3560 & $\mathrm{x}$ & $\mathrm{x}$ & $\mathrm{x}$ & $\mathrm{x}$ \\
\hline Ficus bahiensis C.C.Berg \& Carauta & Tree & CA, CE, MA & MF257 & $\mathrm{x}$ & $\mathrm{x}$ & $\mathrm{x}$ & \\
\hline Ficus gomelleira Kunth & Tree & $\mathrm{CA}, \mathrm{CE}, \mathrm{AM}, \mathrm{MA}$ & MF204 & $\mathrm{x}$ & $\mathrm{x}$ & $\mathrm{x}$ & $\mathrm{x}$ \\
\hline Ficus hirsuta Schott & Tree & $\mathrm{CA}, \mathrm{MA}$ & MF97 & & $\mathrm{x}$ & & $\mathrm{x}$ \\
\hline Sorocea racemosa Gaudich. & Tree & MA & MF452 & & & $\mathrm{x}$ & $\mathrm{x}$ \\
\hline \multicolumn{8}{|l|}{ Myristicaceae } \\
\hline Virola officinalis Warb. & Tree & MA & MF367 & & & & $\mathrm{x}$ \\
\hline \multicolumn{8}{|l|}{ Myrtaceae } \\
\hline Calycolpus legrandii Mattos & Tree & MA & MF205 & & & & $\mathrm{x}$ \\
\hline Calyptranthes restingae Sobral & Tree & MA & MF274 & & $\mathrm{x}$ & $\mathrm{x}$ & \\
\hline $\begin{array}{l}\text { Campomanesia dichotoma (O.Berg) } \\
\text { Mattos }\end{array}$ & Tree & CA, CE, MA & MF307 & $\mathrm{x}$ & & $\mathrm{x}$ & $\mathrm{x}$ \\
\hline Eugenia astringens Cambess. & Tree & MA & MF545 & & $\mathrm{x}$ & $\mathrm{x}$ & $\mathrm{x}$ \\
\hline Eugenia candolleana DC. & Tree & $\mathrm{CA}, \mathrm{CE}, \mathrm{MA}$ & MF547 & & & $\mathrm{x}$ & \\
\hline Eugenia hirta O.Berg & Tree & MA & MF221 & & $\mathrm{x}$ & & \\
\hline Eugenia itacarensis Mattos* & Tree & MA & MF436 & & $\mathrm{x}$ & & \\
\hline Eugenia longifolia DC.* & Tree & MA & EM3568 & $\mathrm{x}$ & $\mathrm{x}$ & & $\mathrm{x}$ \\
\hline Eugenia sp. & Tree & - & MF131 & $\mathrm{x}$ & & & \\
\hline Marlierea glabra Cambess. & Tree & MA & EM3550 & $\mathrm{x}$ & $\mathrm{x}$ & $\mathrm{x}$ & \\
\hline Marlierea obscura O.Berg & Tree & MA & MF539 & $\mathrm{x}$ & $\mathrm{x}$ & & \\
\hline Marlierea obversa D.Legrand & Tree & MA & MF506 & $\mathrm{x}$ & & & $\mathrm{x}$ \\
\hline
\end{tabular}




\begin{tabular}{|c|c|c|c|c|c|c|c|}
\hline Family/Species & Habit & $\begin{array}{c}\text { Phytogeographic } \\
\text { domains }\end{array}$ & Voucher & MC & MMI & MP & MSA \\
\hline Myrcia bergiana O.Berg & Tree & $\mathrm{CA}, \mathrm{MA}$ & MF107 & $\mathrm{x}$ & $\mathrm{x}$ & $\mathrm{x}$ & $\mathrm{x}$ \\
\hline Myrcia grazielae NicLugh.* & Tree & MA & MF546 & $\mathrm{x}$ & & & $\mathrm{x}$ \\
\hline Myrcia guianensis (Aubl.) DC. & Tree & $\mathrm{CA}, \mathrm{CE}, \mathrm{AM}, \mathrm{MA}$ & MF212 & $\mathrm{x}$ & $\mathrm{x}$ & $\mathrm{x}$ & $\mathrm{x}$ \\
\hline Myrcia micropetala (Mart.) Nied. * & Tree & MA & MF550 & & & $\mathrm{x}$ & $\mathrm{x}$ \\
\hline Myrcia ramuliflora (O.Berg) N.Silveira* & Tree & MA & MF234 & $\mathrm{x}$ & $\mathrm{x}$ & & \\
\hline Myrcia salzmannii O.Berg & Tree & MA & MF538 & & $\mathrm{x}$ & & $\mathrm{x}$ \\
\hline Myrcia silvatica (G.Mey.) DC. & Tree & CE, AM, MA & MF115 & $\mathrm{x}$ & & & $\mathrm{x}$ \\
\hline Myrcia sp. & Tree & - & EM3541 & & & & $\mathrm{x}$ \\
\hline Myrcia sp.2 & Tree & - & MF425 & $\mathrm{x}$ & & & \\
\hline Myrcia spectabilis DC. & Tree & MA & MF312 & $\mathrm{x}$ & $\mathrm{x}$ & $\mathrm{x}$ & $\mathrm{x}$ \\
\hline Myrcia splendens (Sw.) DC. & Tree & $\begin{array}{c}\mathrm{AM}, \mathrm{CA}, \mathrm{CE}, \mathrm{MA}, \\
\text { PAN }\end{array}$ & MF132 & $\mathrm{x}$ & $\mathrm{x}$ & $\mathrm{x}$ & $\mathrm{x}$ \\
\hline Myrcia tomentosa (Aubl.) DC. & Tree & $\mathrm{CA}, \mathrm{CE}, \mathrm{AM}, \mathrm{MA}$ & MF168 & & & $\mathrm{x}$ & $\mathrm{x}$ \\
\hline Psidium bahianum Landrum \& Funch* & Tree & MA & MF388 & & & & $\mathrm{x}$ \\
\hline \multicolumn{8}{|l|}{ Nyctaginaceae } \\
\hline Guapira areolata (Heimerl) Lundell & Tree & $\mathrm{CE}, \mathrm{MA}$ & MF246 & $\mathrm{x}$ & $\mathrm{x}$ & & $\mathrm{x}$ \\
\hline Guapira opposita (Vell.) Reitz & Tree & $\mathrm{CA}, \mathrm{CE}, \mathrm{AM}, \mathrm{MA}$ & MF226 & $\mathrm{x}$ & $\mathrm{x}$ & $\mathrm{x}$ & $\mathrm{x}$ \\
\hline Guapira pernambucensis (Casar.) Lundell & Tree & MA & MF492 & & $\mathrm{x}$ & $\mathrm{x}$ & \\
\hline Guapira venosa (Choisy) Lundell & Tree & AM, MA & MF401 & & & $\mathrm{x}$ & $\mathrm{x}$ \\
\hline Neea floribunda Poepp. \& Endl. & Tree & AM, MA & MF167 & & & $\mathrm{x}$ & $\mathrm{x}$ \\
\hline Neea macrophylla Poepp. \& Endl. & Tree & $\mathrm{CE}, \mathrm{AM}, \mathrm{MA}$ & MF288 & $\mathrm{x}$ & $\mathrm{x}$ & $\mathrm{x}$ & $\mathrm{x}$ \\
\hline \multicolumn{8}{|l|}{ Ochnaceae } \\
\hline Ouratea bahiensis Sastre* & Shrub & MA & MF89 & $\mathrm{x}$ & & & $\mathrm{x}$ \\
\hline Ouratea castaneifolia (DC.) Engl. & Tree & $\mathrm{CA}, \mathrm{CE}, \mathrm{AM}, \mathrm{MA}$ & MF368 & & & & $\mathrm{x}$ \\
\hline Ouratea gigantophylla (Erhard) Engl.* & Tree & MA & MF374 & $\mathrm{x}$ & $\mathrm{x}$ & $\mathrm{x}$ & $\mathrm{x}$ \\
\hline Ouratea longipes Sastre* & Shrub & MA & MF303 & & & $\mathrm{x}$ & \\
\hline Ouratea platicaulis Sastre* & Tree & MA & MF497 & $\mathrm{x}$ & $\mathrm{x}$ & $\mathrm{x}$ & $\mathrm{x}$ \\
\hline Ouratea rotundifolia (Gardner) Engl.* & Shrub & MA & MF249 & & $\mathrm{x}$ & & \\
\hline \multicolumn{8}{|l|}{ Olacaceae } \\
\hline Cathedra bahiensis Sleumer* & Tree & MA & MF222 & & & $\mathrm{x}$ & \\
\hline Heisteria perianthomega (Vell.) Sleumer & Tree & $\mathrm{CA}, \mathrm{CE}, \mathrm{AM}, \mathrm{MA}$ & MF210 & & $\mathrm{x}$ & $\mathrm{x}$ & $\mathrm{x}$ \\
\hline \multicolumn{8}{|l|}{ Orchidaceae } \\
\hline Epistephium lucidum Cogn. & Herb & $\mathrm{CA}, \mathrm{CE}, \mathrm{AM}, \mathrm{MA}$ & MF376 & & & & $\mathrm{x}$ \\
\hline Koellensteinia florida (Rchb.f.) Garay & Herb & MA & MF109 & & $\mathrm{x}$ & & \\
\hline Passifloraceae & & & & & & & \\
\hline
\end{tabular}




\begin{tabular}{|c|c|c|c|c|c|c|c|}
\hline Family/Species & Habit & $\begin{array}{c}\text { Phytogeographic } \\
\text { domains }\end{array}$ & Voucher & MC & MMI & MP & MSA \\
\hline Passiflora sidifolia M.Roem. & Vine & MA & MF96 & & $\mathrm{x}$ & & \\
\hline Passiflora silvestris Vell. & Vine & CE, MA & MF328 & $\mathrm{x}$ & & & \\
\hline Passiflora watsoniana Mast. & Vine & MA & MF457 & & & $\mathrm{x}$ & \\
\hline \multicolumn{8}{|l|}{ Peraceae } \\
\hline Pera glabrata (Schott) Poepp. ex Baill. & Tree & CA, CE, AM, MA & MF251 & $\mathrm{x}$ & $\mathrm{x}$ & $\mathrm{x}$ & $\mathrm{x}$ \\
\hline $\begin{array}{l}\text { Pogonophora schomburgkiana Miers ex } \\
\text { Benth. }\end{array}$ & Tree & CA, CE, AM, MA & MF370 & $\mathrm{x}$ & $\mathrm{x}$ & $\mathrm{x}$ & $\mathrm{x}$ \\
\hline \multicolumn{8}{|l|}{ Phyllantaceae } \\
\hline Richeria grandis Vahl & Tree & CA, CE, AM, MA & MF164 & $\mathrm{x}$ & $\mathrm{x}$ & $\mathrm{x}$ & $\mathrm{x}$ \\
\hline \multicolumn{8}{|l|}{ Piperaceae } \\
\hline Piper aduncum L. & Tree & $\begin{array}{l}\text { AM, CA, CE, MA, } \\
\text { PAN, PAM }\end{array}$ & MF396 & & & & $\mathrm{x}$ \\
\hline Piper amplum Kunth & Shrub & CE, MA & MF399 & & & & $\mathrm{x}$ \\
\hline Piper ilheusense Yunck. & Shrub & MA & MF75 & $\mathrm{x}$ & $\mathrm{x}$ & $\mathrm{x}$ & \\
\hline \multicolumn{8}{|l|}{ Poaceae } \\
\hline $\begin{array}{l}\text { Parodiolyra ramosissima (Trin.) Soderstr. } \\
\text { \& Zuloaga* }\end{array}$ & Herb & MA & MF382 & & $\mathrm{x}$ & & \\
\hline \multicolumn{8}{|l|}{ Polygalaceae } \\
\hline Bredemeyera disperma (Vell.) J.F.B.Pastore & Vine & MA & MF92 & $\mathrm{x}$ & & $\mathrm{x}$ & \\
\hline \multicolumn{8}{|l|}{ Polygonaceae } \\
\hline Coccoloba laevis Casar. & Tree & $\mathrm{CA}, \mathrm{MA}$ & MF244 & $\mathrm{x}$ & & & $\mathrm{x}$ \\
\hline Coccoloba marginata Benth. & Tree & CE, AM, MA & MF209 & $\mathrm{x}$ & $\mathrm{x}$ & & \\
\hline Coccoloba oblonga Lindau* & Shrub & MA & MF218 & $\mathrm{x}$ & & $\mathrm{x}$ & \\
\hline Coccoloba parimensis Benth. & Shrub & CA, CE, AM, MA & MF279 & & & & $\mathrm{x}$ \\
\hline Coccoloba rosea Meisn. & Tree & MA & MF119 & $\mathrm{x}$ & $\mathrm{x}$ & $\mathrm{x}$ & $\mathrm{x}$ \\
\hline \multicolumn{8}{|l|}{ Primulaceae } \\
\hline Cybianthus amplus (Mez) G.Agostini & Tree & AM, MA & MF438 & & $\mathrm{x}$ & $\mathrm{x}$ & \\
\hline Cybianthus densiflorus Miq. & Tree & AM, MA & MF245 & $\mathrm{x}$ & $\mathrm{x}$ & $\mathrm{x}$ & $\mathrm{x}$ \\
\hline \multicolumn{8}{|l|}{ Rubiaceae } \\
\hline $\begin{array}{l}\text { Amaioua intermedia Mart. ex Schult. \& } \\
\text { Schult.f. }\end{array}$ & Tree & CE, MA & MF208 & $\mathrm{x}$ & $\mathrm{x}$ & $\mathrm{x}$ & \\
\hline Chiococca alba (L.) Hitchc. & Shrub & $\begin{array}{l}\text { AM, CA, CE, MA, } \\
\text { PAN }\end{array}$ & MF427 & $\mathrm{x}$ & $\mathrm{x}$ & $\mathrm{x}$ & $\mathrm{x}$ \\
\hline Coussarea graciliflora (Mart.) Müll.Arg. & Shrub & MA & MF407 & & $\mathrm{x}$ & & \\
\hline Faramea coerulea (Nees \& Mart.) DC. & Shrub & MA & MF280 & & $\mathrm{x}$ & & \\
\hline Faramea nocturna J.G.Jardim \& Zappi* & Tree & MA & MF349 & & $\mathrm{x}$ & $\mathrm{x}$ & $\mathrm{x}$ \\
\hline $\begin{array}{l}\text { Margaritopsis chaenotricha (DC.) } \\
\text { C.M.Taylor }\end{array}$ & Shrub & MA & MF217 & $\mathrm{x}$ & & & \\
\hline
\end{tabular}




\begin{tabular}{|c|c|c|c|c|c|c|c|}
\hline Family/Species & Habit & $\begin{array}{c}\text { Phytogeographic } \\
\text { domains }\end{array}$ & Voucher & MC & MMI & MP & MSA \\
\hline Melanopsidium nigrum Colla & Tree & CE, MA & MF453 & $\mathrm{x}$ & $\mathrm{x}$ & & \\
\hline Mitracarpus salzmannianus DC. & Herb & $\mathrm{CA}, \mathrm{CE}, \mathrm{AM}, \mathrm{MA}$ & MF71 & & & $\mathrm{x}$ & $\mathrm{x}$ \\
\hline Pagamea guianensis Aubl. & Shrub & $\mathrm{CA}, \mathrm{CE}, \mathrm{AM}, \mathrm{MA}$ & MF377 & $\mathrm{x}$ & $\mathrm{x}$ & $\mathrm{x}$ & $\mathrm{x}$ \\
\hline Pagamea harleyi Steyerm.* & Tree & MA & MF262 & & $\mathrm{x}$ & $\mathrm{x}$ & \\
\hline Palicourea guianensis Aubl. & Tree & $\mathrm{CE}, \mathrm{AM}, \mathrm{MA}$ & MF146 & $\mathrm{x}$ & $\mathrm{x}$ & $\mathrm{x}$ & $\mathrm{x}$ \\
\hline Psychotria bahiensis DC. & Shrub & $\mathrm{CA}, \mathrm{CE}, \mathrm{MA}$ & MF70 & $\mathrm{x}$ & $\mathrm{x}$ & $\mathrm{x}$ & $\mathrm{x}$ \\
\hline Psychotria cupularis (Müll.Arg.) Standl. & Tree & AM, MA & MF362 & & $\mathrm{x}$ & & \\
\hline Psychotria jambosioides Schltdl.* & Shrub & MA & MF137 & $\mathrm{x}$ & $\mathrm{x}$ & $\mathrm{x}$ & $\mathrm{x}$ \\
\hline Psychotria mapourioides DC. & Tree & AM, MA & MF426 & $\mathrm{x}$ & $\mathrm{x}$ & $\mathrm{x}$ & $\mathrm{x}$ \\
\hline $\begin{array}{l}\text { Psychotria schlechtendaliana (Müll.Arg.) } \\
\text { Müll.Arg. }\end{array}$ & Shrub & $\mathrm{CA}, \mathrm{MA}$ & MF124 & $\mathrm{x}$ & & & \\
\hline Psychotria stachyoides Benth. & Shrub & $\mathrm{CA}, \mathrm{CE}, \mathrm{MA}$ & MF300 & $\mathrm{x}$ & & & \\
\hline Psychotria vellosiana Benth. & Tree & $\mathrm{CA}, \mathrm{CE}, \mathrm{MA}$ & MF383 & & $\mathrm{x}$ & & \\
\hline Randia calycina Cham. & Tree & $\mathrm{CE}, \mathrm{AM}, \mathrm{MA}$ & MF321 & & & $\mathrm{x}$ & $\mathrm{x}$ \\
\hline Rudgea interrupta Benth. & Shrub & MA & MF465 & $\mathrm{x}$ & $\mathrm{x}$ & & \\
\hline Salzmannia nitida DC. & Shrub & MA & MF214 & $\mathrm{x}$ & $\mathrm{x}$ & $\mathrm{x}$ & \\
\hline \multicolumn{8}{|l|}{ Rutaceae } \\
\hline Rauia nodosa (Engl.) Kallunki & Tree & MA & MF455 & & & & $\mathrm{x}$ \\
\hline \multicolumn{8}{|l|}{ Salicaceae } \\
\hline Casearia arborea (Rich.) Urb. & Tree & $\mathrm{CE}, \mathrm{AM}, \mathrm{MA}$ & MF435 & $\mathrm{x}$ & $\mathrm{x}$ & $\mathrm{x}$ & $\mathrm{x}$ \\
\hline Casearia commersoniana Cambess. & Tree & $\mathrm{CA}, \mathrm{CE}, \mathrm{AM}, \mathrm{MA}$ & MF85 & $\mathrm{x}$ & $\mathrm{x}$ & $\mathrm{x}$ & $\mathrm{x}$ \\
\hline \multicolumn{8}{|l|}{ Sapindaceae } \\
\hline Cupania oblongifolia Mart. & Tree & $\mathrm{CE}, \mathrm{AM}, \mathrm{MA}$ & MF325 & & & & $\mathrm{x}$ \\
\hline Cupania racemosa (Vell.) Radlk. & Tree & $\mathrm{CA}, \mathrm{CE}, \mathrm{AM}, \mathrm{MA}$ & MF126 & $\mathrm{x}$ & $\mathrm{x}$ & & \\
\hline Matayba discolor (Spreng.) Radlk. & Tree & MA & MF84 & & & $\mathrm{x}$ & \\
\hline Paullinia racemosa Wawra & Vine & MA & MF230 & $\mathrm{x}$ & $\mathrm{x}$ & $\mathrm{x}$ & $\mathrm{x}$ \\
\hline Serjania salzmanniana Schltdl. & Vine & $\mathrm{CE}, \mathrm{AM}, \mathrm{MA}$ & MF94 & $\mathrm{x}$ & $\mathrm{x}$ & $\mathrm{x}$ & $\mathrm{x}$ \\
\hline Talisia macrophylla (Mart.) Radlk. & Tree & AM, MA & MF429 & & & & $\mathrm{x}$ \\
\hline \multicolumn{8}{|l|}{ Sapotaceae } \\
\hline Chrysophyllum flexuosum Mart. & Tree & MA & MF519 & $\mathrm{x}$ & & $\mathrm{x}$ & \\
\hline Diploon cuspidatum (Hoehne) Cronquist & Tree & AM, MA & MF369 & $\mathrm{x}$ & $\mathrm{x}$ & & \\
\hline Ecclinusa guianensis Eyma & Tree & AM, MA & MF351 & $\mathrm{x}$ & $\mathrm{x}$ & $\mathrm{x}$ & $\mathrm{x}$ \\
\hline Manilkara salzmannii (A.DC.) H.J.Lam & Tree & MA & MF315 & $\mathrm{x}$ & $\mathrm{x}$ & $\mathrm{x}$ & $\mathrm{x}$ \\
\hline $\begin{array}{l}\text { Micropholis crassipedicellata (Mart. \& } \\
\text { Eichler) Pierre }\end{array}$ & Tree & MA & MF366 & & & & $\mathrm{x}$ \\
\hline Micropholis emarginata T.D.Penn.* & Tree & $\mathrm{CA}, \mathrm{CE}, \mathrm{MA}$ & MF445 & & & $\mathrm{x}$ & \\
\hline
\end{tabular}




\begin{tabular}{|c|c|c|c|c|c|c|c|}
\hline Family/Species & Habit & $\begin{array}{c}\text { Phytogeographic } \\
\text { domains }\end{array}$ & Voucher & MC & MMI & MP & MSA \\
\hline Micropholis gardneriana (A.DC.) Pierre & Tree & CA, CE, AM, MA & MF294 & $\mathrm{x}$ & $\mathrm{x}$ & & \\
\hline Pouteria butyrocarpa (Kuhlm.) T.D.Penn.* & Tree & MA & MF330 & & & & $\mathrm{x}$ \\
\hline Pouteria coelomatica Rizzini & Tree & MA & MF329 & $\mathrm{x}$ & $\mathrm{x}$ & & $\mathrm{x}$ \\
\hline Pouteria cuspidata (A.DC.) Baehni & Tree & CE, AM, MA & MF304 & & $\mathrm{x}$ & & \\
\hline Pouteria guianensis Aubl. & Tree & AM, MA & MF331 & & $\mathrm{x}$ & $\mathrm{x}$ & \\
\hline Pouteria macahensis T.D.Penn. & Tree & MA & MF 414 & $\mathrm{x}$ & & & \\
\hline Pradosia lactescens (Vell.) Radlk. & Tree & MA & MF332 & & $\mathrm{x}$ & $\mathrm{x}$ & $\mathrm{x}$ \\
\hline \multicolumn{8}{|l|}{ Schoepfiaceae } \\
\hline Schoepfia brasiliensis A.DC. & Tree & CE, AM, MA & MF265 & & $\mathrm{x}$ & & \\
\hline \multicolumn{8}{|l|}{ Siparunaceae } \\
\hline Siparuna cymosa Tolm. & Tree & AM, MA & MF291 & & & & $\mathrm{x}$ \\
\hline \multicolumn{8}{|l|}{ Smilacaceae } \\
\hline Smilax campestris Griseb. & Vine & CA, CE, MA, PAM & MF441 & $\mathrm{x}$ & $\mathrm{x}$ & $\mathrm{x}$ & \\
\hline \multicolumn{8}{|l|}{ Solanaceae } \\
\hline Cestrum salzmannii Dunal & Shrub & MA & MF405 & $\mathrm{x}$ & & $\mathrm{x}$ & $\mathrm{x}$ \\
\hline Solanum asperum Rich. & Shrub & CA, CE, AM, MA & MF404 & & & $\mathrm{x}$ & $\mathrm{x}$ \\
\hline Solanum rupincola Sendtn. & Vine & MA & MF375 & & $\mathrm{x}$ & $\mathrm{x}$ & \\
\hline \multicolumn{8}{|l|}{ Stemonuraceae } \\
\hline Discophora guianensis Miers & Tree & AM, MA & MF127 & & $\mathrm{x}$ & & $\mathrm{x}$ \\
\hline \multicolumn{8}{|l|}{ Thymaelaeceae } \\
\hline Daphnopsis racemosa Griseb. & Tree & CE, MA & MF269 & & $\mathrm{x}$ & $\mathrm{x}$ & $\mathrm{x}$ \\
\hline \multicolumn{8}{|l|}{ Triuridaceae } \\
\hline Peltophyllum luteum Gardner & Herb & MA & MF72 & $\mathrm{x}$ & & & $\mathrm{x}$ \\
\hline \multicolumn{8}{|l|}{ Urticaceae } \\
\hline Cecropia pachystachya Trécul & Tree & $\begin{array}{c}\text { AM, CA, CE, MA, } \\
\text { PAN }\end{array}$ & MF397 & $\mathrm{x}$ & $\mathrm{x}$ & $\mathrm{x}$ & \\
\hline \multicolumn{8}{|l|}{ Verbenaceae } \\
\hline Lippia macrophylla Cham.* & Shrub & CE, MA & MF339 & $\mathrm{x}$ & $\mathrm{x}$ & $\mathrm{x}$ & \\
\hline \multicolumn{8}{|l|}{ Violaceae } \\
\hline Paypayrola blanchetiana Tul. & Tree & MA & MF386 & $\mathrm{x}$ & & & \\
\hline Rinorea bahiensis (Moric.) Kuntze & Tree & MA & MF148 & $\mathrm{x}$ & & $\mathrm{x}$ & \\
\hline
\end{tabular}




\section{Acknowledgements}

We are greatful to the following specialists for helping with plant identification: Adriana Q. Lobão (Annonaceae), Alessandro Rapini (Apocynaceae), Ana L. A. Côrtes (Acanthaceae), Anderson F. Machado (Cannabaceae, Moraceae and Urticaceae), André M. Amorim (Malpighiaceae and Violaceae), Cláudia E. Carneiro (Sapotaceae), Daniela S. CarneiroTorres (Euphorbiaceae), Denis N. de Carvalho (Orchidaceae), Efigênia Melo (Dilleniaceae, Lacistemataceae and Polygonaceae), Eudes B. Mattos (Ericaceae), Fábio S. do Espírito-Santo (Bignoniaceae), Fabrício M. Ferreira (Poaceae), Fernanda O. Silva (Ochnaceae), Flávio França e Raymond M. Harley (Lamiaceae), Francisco S. Souza (Nyctaginaceae), Gabriela B. Siqueira (Gentianaceae), Herlon A. Santos (Carycaceae), Jefferson G. Carvalho-Sobrinho (Malvaceae), Jomar G.Jardim (Achariaceae and Rubiaceae), José F. B. Pastore (Polygalaceae), Juliana G. Freitas (Cyclanthaceae and Melastomataceae), Karoline C. de Santana (Myrtaceae), Larry Noblick (Arecaceae), Lucas Marinho (Clusiaceae and Hypericaceae), Maria B. B.Alves (Asteraceae), Matheus G. C. Nogueira (Bromeliaceae), Ricardo de O. Perdiz (Burseraceae and Sapindaceae), Tânia R. S. Silva (Verbenaceae), Teonildes S. Nunes (Passifloraceae), Thiago A. Pontes (Araceae), Thiago F. de Araújo (Erythroxylaceae). We are also greatful to André M. Amorim, Jomar G. Jardim, Marcelo Moro and two anonymous reviewers for their helpful considerations on the manuscript. This study is part of the M.Sc. thesis of MFF, developed at PPGBot-UEFS, with a fellowship from Coordenação de Aperfeiçoamento de Pessoal de Nível Superior (CAPES). The research was supported by the project "Padrões de diversidade de leguminosas nos biomas brasileiros: ligando taxonomia e moléculas para o entendimento da evolução da biota do Brasil" (Sisbiota CNPq processo 563084/2010-3 / Fapesb PES 0053/2011).

\section{References}

Addinsoft. 2007. XLSTAT: Analyse de données et statistique avec MS Excel. Addinsoft. New York. Disponível em $<$ http://www.xlstat.com/ $>$. Acesso em 03 julho 2014.

Almeida Jr., E.B.; Olivo, M.A.; Araujo, E.L. \& Zickel, C.S. 2009. Caracterização da vegetação de restinga da RPPN de Maracaípe, PE, Brasil, com base na fisionomia, flora, nutrientes do solo e lençol freático. Acta Botanica Brasilica 23: 36-48.

Alvares, C.A.; Stape, J.L.; Sentelhas, P.C.; Gonçalves, J.L.M. \& Sparovek, G. 2013. Köppen's climate classification map for Brazil. Meteorologische Zeitchrift 22: 711-728.

Amorim, A.M.; Thomas, W.W.; Carvalho, A.M.V. \& Jardim, J.G. 2008. Floristic of the Una Biological Reserve, Bahia, Brazil. In: Thomas, W.W. (ed.). The atlantic coastal forests of northeastern Brazil. Memorial of the New York Botanical Garden, New York. 586p.

Amorim, A.M.; Jardim, J.G.; Lopes, M.M.M.; Fiaschi, P.; Borges, R.A.X.; Perdiz, R.O. \& Thomas, W.W. 2009. Angiospermas em remanescentes de floresta montana no sul da Bahia, Brasil. Biota Neotropica 9: 313-348.

APG III - Angiosperm Phylogeny Group. 2009. An update of the Angiosperm Phylogeny Group classification for the orders and families of flowering plants: APG III. Botanical Journal of Linnean Society 161:105-121.

Araujo, D.S.D. 2000. Análise florística e fitogeográfica das restingas do Estado do Rio de Janeiro. Tese de Doutorado. Instituto de Biologia. Universidade Federal do Rio de Janeiro, Rio de Janeiro. 176p.

Araújo, D.S.D. \& Henriques, R.P.B. 1984. Análise florística das restingas do Estado do Rio de Janeiro. In: L.D. Lacerda; D.S.D. Araujo; R. Cerqueira \& B. Turcq (eds.). Restingas: Origem, Estrutura e Processos. CEUFF, Niterói, Rio de Janeiro. Pp. 159-194.

Assis, A.M.; Thomaz, L.D. \& Pereira, O.J. 2004. Florística de um trecho de floresta de restinga no município de Guarapari, Espírito Santo, Brasil. Acta Botanica Brasilica 18: 191-201.

Assis, M.A., Prata, E.M.B., Pedroni, F., Sanchez, M., Eisenlohr, P.V., Martins, F.R., Santos, F.A.M., Tamashiro, J.Y., Alves, L.F., Vieira, S.A., Piccolo, M.C., Martins, S.C., Camargo, P.B., Carmo, J.B., Simões, E., Martinelli, L.A. \& Joly, C.A. 2011. Florestas de restinga e de terras baixas na planície costeira do sudeste do Brasil: vegetação e heterogeneidade ambiental. Biota Neotropica 11: 103-121.

Assumpção, J. \& Nascimento, M.T. 2000. Estrutura e composição florística de quatro formações vegetais de restinga no complexo lagunar Grussaí/Iquipari, São João da Barra, R.J, Brasil. Acta Botanica Brasilica 14: 301-315.

Berry, E.W. 1915. The origin and distribution of the family Myrtaceae. Botanical Gazette 59: 484-490.

Bigarella, J.J. \& Andrade-Lima, D. 1982. Paleoenvironmental changes in Brazil. In: Biological diversification in the Tropics. Plenum Press, New York. Pp. 27-40.

Borgo, M. \& Silva, S.M. 2003. Epífitos vasculares em fragmentos de Floresta Ombrófila Mista, Curitiba, 
Paraná, Brasil. Revista Brasileira de Botânica 26: 391-401.

Britto, I.C.; Queiroz, L.P.; Guedes, M.L.S.; Oliveira, N.C. \& Silva, L.B. 1993. Flora fanerogâmica das dunas e lagoas do Abaeté, Salvador, Bahia. Sitientibus 11: 31-46.

Carnaval, A.C. \& Moritz, C. 2008. Historical climate modelling predicts patterns of current biodiversity in the brazilian atlantic forest. Journal of Biogeography 35: 1187-1201.

Castro, A.S.F.; Moro, M.F. \& Menezes, M.O.T. 2012. O Complexo Vegetacional da Zona Litorânea no Ceará: Pecém, São Gonçalo do Amarante. Acta Botanica Brasilica 26: 108-124.

C.E.I - Centro de Estatística e Informações - BA. 1993. Informações básicas dos municípios baianos: região litoral sul. Salvador. 559p.

Cerqueira, R. 2000. Biogeografia das restingas. In: Esteves, F.A.; Lacerda, L.D. (eds.) Ecologia de restingas e lagoas costeiras. NUPEM/UFRJ, Macaé. Pp. 65-76.

Dorneles, L.P.P. \& Waechter, J.L. 2004. Estrutura do componente arbóreo da floresta arenosa de restinga do Parque Nacional da Lagoa do Peixe, Rio Grande do Sul. Hoehnea 31: 61-71.

Flexor, J.M.; Martin, L.; Suguio, K. \& Dominguez, J.M.L. 1984. Gênese dos cordões litorâneos da parte central da costa brasileira. In: Lacerda, L.D.; Araújo, D.S.D.; Cerqueira R. \& Turcq, B. (orgs.). Restingas: origem, estruturas, processos. CEUFF, Niterói. Pp. 35-46.

Giongo, C. \& Waechter, J.L. 2004. Composição florística e estrutura comunitária de epífitos vasculares em uma floresta de galeria na Depressão Central do Rio Grande do Sul. Revista Brasileira de Botânica. 27: 563-572.

Guedes, D.; Barbosa, L.M. \& Martins, S.E. 2006. Composição florística e estrutura fitossociológica de dois fragmentos de floresta de restinga no município de Bertioga, SP, Brasil. Acta Botanica Brasilica. 20: 299-311.

Hammer, O.; Harper, A.T.D. \& Ryan, P.D. 2001. Past: Paleontological statistics software package for education and data analysis. Palaeontologia Electronica 4: 1-9.

Koeppen, W. 1948. Climatologia - con un estudio de los climas de la tierra. Fondo de cultura económica, Ciudad de México. 479p.

Lacerda, L.D. 1984. Restingas: origem, estrutura, processos. In: Anais do simpósio sobre restingas brasileiras. Universidade Federal Fluminense, Rio de Janeiro. Pp. 10-14.

Lima, R.A.F.; Oliveira, A. A.; Martini, A.M.Z.; Sampaio, D.; Souza, V.C. \& Rodrigues, R.R. 2011. Structure, diversity, and spatial patterns in a permanent plot of a high restinga forest in southeastern Brazil. Acta Botanica Brasílica 25: 633-645.
Lista de Espécies da Flora do Brasil. Jardim Botânico do Rio de Janeiro. Disponível em: < http://floradobrasil. jbrj.gov.br/>. Acesso em 28 junho 2014

Magnago, L.F.S.; Martins, S.V. \& Pereira, O.J. 2011. Heterogeneidade florística das fitocenoses de restingas nos estados do Rio de Janeiro e Espírito Santo, Brasil. Revista Árvore 35: 245-254.

Martin, L.; Bittencourt, A.C.S.P.; Vilas Boas, G.S. \& Flexor, J.M. 1980. Texto explicativo para o mapa geológico do quaternário costeiro do estado da Bahia - escala 1.250.000. COM/SME, Salvador. $60 \mathrm{p}$.

Martins S.E.; Rossi, L.; Sampaio, P.S.P. \& Galvão, M.M.A. 2008. Caracterização florística de comunidades vegetais de restinga em Bertioga, SP, Brasil. Acta Botânica Brasilica 22: 249-274.

Menezes, C.M.; Aguiar, L.G.P.A.; Espinheira, M.J.C.L. \& Silva, V.I.S. 2009. Florística e fitossociologia do componente arbóreo do município de Conde, Bahia, Brasil. Revista Biociências 15: 44-55.

Mori, S.A.; Boom, B.M. \& Prance, G.T. 1981. Distribution patterns and conservation of eastern Brazilian coastal forest tree species. Brittonia 33: 233-245.

Mori, S.A.; Silva, L.A.M.; Lisboa, G. \& Coradin, L. 1989. Manual de manejo do herbário fanerogâmico. Centro de Pesquisa do Cacau, Ilhéus. 97p.

Mueller-Dombois, D. \& Ellenberg, H. 1974. Aims and methods of vegetation ecology. John Wiley, New York. 547p.

Murray-Smith, C.; Brummitt, N.A.; Oliveira-Filho, A.T.; Bachman, S.P.; Moat, J.; Nic Lughadha, E.M.N. \& Lucas, E.J. 2008. Plant diversity hotspots in the atlantic coastal forest of Brazil. Conservation Biology 23: 151-163.

Oliveira-Filho, A.T. \& Ratter, J.A. 1995. A study of the origin of central Brazilian forests by the analysis of plant species distribution patterns. Edinburgh Journal of Botany 52: 141-194.

Oliveira Filho A.T. \& Fontes, M.A.L. 2000. Patterns of floristic differentiation among atlantic forests in southeastern Brazil and the influence of climate. Biotropica 32: 793-810.

Peel, M.C.; Finlayson, B.L. \& McMahon, T.A. 2007. Updated world map of the Köppen-Geiger climate classification. Hydrology and Earth System Sciences 11: 1633-1644.

Pereira, O.J.; Assis, A.M. \& Souza, R.L.D. 1998. Vegetação da restinga de Pontal do Ipiranga, município de Linhares (ES). In: Anais do IV simpósio de ecossistemas brasileiros. ACIESP, São Paulo. Pp. 117-128.

Pereira, O.J. \& Araujo, D.S.D. 2000. Análise florística das restingas dos estados do Espírito Santo e Rio de Janeiro. In: F.A. Esteves \& L.D. Lacerda (eds.). Ecologia de eestingas e lagoas costeiras. NUPEM/ UFRJ, Macaé. Pp. 25-63. 
Queiroz, E.P. 2007. Levantamento florístico e georreferenciamento das espécies com potencial econômico e ecológico em restinga de Mata de São João, Bahia, Brasil. Biotemas. 20: 41-47.

Queiroz, E.P.; Cardoso, D.B.O.S. \& Santos, M.H. 2012. Composição florística da vegetação de restinga da APA Rio Capivara, Litoral Norte da Bahia, Brasil. Sitientibus 12: 119-141.

Ratter, J.A.; Bridgewater, S. \& Ribeiro, J.F. 2003. Analysis of the floristic composition of the Brazilian cerrado vegetation iii: comparison of the woody vegetation of 376 areas. Edinburgh Journal of Botany 60: 57-109.

Rocha, C.F.D.; Van Sluys, M., Bergallo, H.G. \& Alves, M.A.S. 2005. Endemic and threatened tetrapods in the restingas of the biodiversity corridors of Serra do Mar and of the central mata atlântica in eastern Brazil. Brazilian Journal of Biology 65:159-168.

Rocha, C.F.D.; Bergallo, H.G.; van Sluys, M.; Alves, M.A.S. \& Jamel, C.E. 2007. The remnants of restinga habitats in the brazilian atlantic forest of Rio de Janeiro state, Brazil: habitat loss and risk of disappearance. Brazilian Journal of Biology 67: 263-273.

Sacramento, A.C.; Zieckel, C.S. \& Almeida Jr., E.B. 2007. Aspectos florísticos da vegetação de restinga no litoral de Pernambuco. Revista Árvore 31: 1121-1130

Santos, R.; Silva, R.C.; Pacheco, D.; Martins, R. \& Citadini-Zanette, V. 2012. Florística e estrutura do componete arbustivo-arbóreo de mata de restinga arenosa no Parque Estadual de Itapeva, Rio Grande do Sul. Revista Árvore 36: 1047-1059.

Scarano, F.R. 2002. Structure, function and floristic relationships of plant communities in stressful habitats marginal to the brazilian atlantic rainforest. Annals of Botany 90: 517-524.

Scarano, F.R. 2009. Plant communities at the periphery of the Atlantic rain forest: Rare-species bias and its risks for conservation. Biological Conservation 142: 1201-1208.
Scherer, A.; Maraschin-Silva, F. \& Baptista, L.R.M. 2005. Florística e estrutura do componente arbóreo de matas de restinga arenosa no Parque Estadual de Itapuã, RS, Brasil. Acta Botanica Brasilica 19: 717-726.

Silva, S.M. \& Britez, R.M. 2005. A vegetação da planície costeira. In: Marques, M.C.M.; Britez, R.M. (org.). História natural e conservação da Ilha do Mel. Universidade Federal do Paraná, Curitiba. Pp. 49-84.

Silva, S.S.L.; Zickel, C.S. \& Cestaro, L.A. 2008. Flora vascular e perfil fisionômico de uma restinga no litoral sul de Pernambuco, Brasil. Acta Botanica Brasilica 22: 1123-1135.

Smith, L.B. \& Downs R.J. 1979. Bromelioideae (Bromeliaceae). Flora Neotropica Monograph 14: 1493-2141.

Stehmann, J.R.; Forzza, R.C.; Salino, A.; Sobral, M.; Costa, D.P. \& Kamino, L.H.Y. (eds). 2009. Plantas da Floresta Atlântica. Jardim Botânico do Rio de Janeiro, Rio de Janeiro. 505p.

Sugiyama, M. 1998. Estudo de florestas de restinga na Ilha do Cardoso, Cananéia, São Paulo, Brasil. Boletim do Instituto de Botânica 11: 119-159.

Tropicos. Mobot. Missouri botanical garden. Disponível em $<$ http://www.tropicos. org $>$. Acesso em 03 julho 2014.

Thomas, W.W.; Carvalho, A.M.V.; Amorim, A.M.A.; Garrison, J. \& Arbeláez, A.L. 1998. Plant endemism in two forests in southern Bahia, Brazil. Biodiversity and Conservation 7: 311-322.

Villwock, J.A.; Lessa, G.C.; Suguio, K.; Angulo, R.J. \& Dillenburg, S.R. 2005. Geologia e geomorfologia de regiões costeiras. In: Souza, C.R.G.; Suguio, K.; Oliveira, A.M.S. Quaternário do Brasil. Holos Editora, Ribeirão Preto. Pp. 94-113.

Ward, M.; Dick, C.W.; Gribel, R. \& Lowe, A.J. 2005. To self, or not to self... A review of outcrossing and pollen-mediated gene flow in neotropical trees. Heredity 95: 246-254.

Whittaker, R. H. 1975. Communities and Ecossystems. Macmillan, New York. 352p. 


\section{Supplementary material}

S1 - Presence-absence matrix based on the species lists of all of the sites used in the similarity and cluster analyses, with their respective occurrences in each area (Word format).

S1 - Matriz de presença-ausência contendo a lista de espécies em todas as áreas utilizadas nas análises de similaridade e agrupamento com suas respectivas ocorrências em cada local, em formato Word.

S2 - Presence-absence matrix based on the species lists of all of the sites used in the similarity and cluster analyses, with their respective occurrences in each area (TXT format).

S2 - Matriz de presença-ausência contendo a lista de espécies em todas as áreas utilizadas nas análises de similaridade e agrupamento com suas respectivas ocorrências em cada local, em formato TXT.

S3 - List of the Angiosperm species sampled at Maraú-Itacaré: MC= Mata do Caubi; MMI= Mata estrada Maraú-Itacaré; MP= Mata Piracanga; $\mathrm{MAS}=$ Mata do Santo Amaro. Brazilian phytogeographic domains: $\mathrm{AM}=$ Amazonian, $\mathrm{CA}=\mathrm{Caatinga}, \mathrm{CE}=\mathrm{Cerrado}, \mathrm{MA}=$ Atlantic Forest, PAM=Pampa, PAN= Pantanal. Collectors: EM= Eloína Neri de Matos; MF= Moabe Ferreira Fernandes. $*=$ Species endemic to southeastern Bahia and northern Espírito Santo states.

S3 - Lista das espécies de Angiospermas amostradas nas florestas de Restinga da região de Maraú-Itacaré: MC= Mata do Caubi; $\mathrm{MMI}=$ Mata estrada Maraú-Itacaré; $\mathrm{MP}=$ Mata Piracanga; MAS= Mata do Santo Amaro. Domínios fitogeográficos: AM=Amazônia, $\mathrm{CA}=$ Caatinga, $\mathrm{CE}=$ Cerrado, $\mathrm{MA}=$ Mata Atlântica, $\mathrm{PAM}=$ Pampa, $\mathrm{PAN}=$ Pantanal. Coletores: $\mathrm{EM}=$ Eloína Neri de Matos; $\mathrm{MF}=\mathrm{Moabe}$ Ferreira Fernandes. *=Endêmicas do sul da Bahia e norte do Espírito Santo.

S4 - Photographs of the four sites surveyed in the present study: A-B: Mata do Santo Amaro; C-D: Mata do Caubi; E-F: Mata da Estrada Maraú-Itacaré; G-H: Mata da Piracanga.

S4 - Fotografias dos quatro sítios inventariados neste estudo: A-B: Mata do Santo Amaro; C-D: Mata do Caubi; E-F: Mata da Estrada Maraú-Itacaré; G-H: Mata da Piracanga. 